\title{
VICISITUDES DE LA DOCUMENTACIÓN MEDIEVAL DEL MONASTERIO CISTERCIENSE DE FITERO ${ }^{1}$
}

\author{
THE VICISSITUDES OF THE DOCUMENTATION \\ OF THE MEDIEVAL CISTERCIAN MONASTERY OF FITERO
}

\author{
$\mathrm{M}^{\mathrm{a}}$ Isabel OSTOLAZA ELIZONDO \\ Universidad Pública de Navarra \\ Cristina MONTERDE ALBIAC \\ Universidad de Zaragoza \\ Ignacio PANIZO SANTOS \\ Archivo Histórico Nacional (Madrid)
}

Resumen: El artículo estudia la historia del archivo del monasterio cisterciense de Fitero (Navarra) en la Edad Media, contrastando la documentación existente con las referencias de la misma en diversos inventarios archivísticos de la edad moderna. Se han conservado un total de 135 documenrtos medievales posteriores a 1210 (fecha en que se terminó el Cartulario de Fitero), de los que 65 son originales y el resto copias de privilegios importantes que se querían preservar en el archivo monástico, utilizando en su lugar versiones más tardías cuando había que demostrar los derechos de la entidad. O conseguidas a partir del s. XVI con ocasión de las demandas presentadas por el monasterio en defensa de sus intereses, ante los tribunales navarros y en menor medida castellanos.

El cotejo de la documentación con los inventarios de archivo de los s. XVII y XVIII, ha permitido determinar que ya en esa época se había detectado la pérdida de algunos originales importantes, poniéndose gran cuidado en la preservación de los restantes. De lo que se deduce que los efectos negativos para la conservación del patrimonio documental achacables entre otras causas a la Desamortización de Mendizábal, se convierten hasta cierto punto en un tópico no corroborado en el
Abstract: The article studies the history of the archives of the Cistercian monastery at Fitero (Navarre) in the Middle Ages, comparing the documentation available with references to it in a number of archive inventories of the modern age. A total of 135 mediaeval documents dated after 1210 have been conserved (the year in wich the Cartulary of Fitero was completed), of which 65 are originals and the rest copies of important privileges that were conserved in the monastery's archives, using later versions in their place when it was necessary to demonstrate the monastery's rigths. Others were obtained from the $16^{\text {th }}$ century onwards as a result of claims presented by the monastery in defence of its interest before the courts of law of Navarre, and to a lesser extent those of Spain.

The comparison of the documentation with the archive inventories of the $17^{\text {th }}$ and $18^{\text {th }}$ centuries has enabled us to determine that the loss of some important original documents had been detected at the time, and great care was taken to preserve the remaining items. From this it can be deduced that the negative effects on the conservation of the documentary patrimony, due to the Desamortización (confiscation of church property) of Mendizábal, among other things, became a 
caso del archivo fiterense, que afortunadamente ha conservado la mayor parte de su documentación medieval.

Palabras clave: archivo del monasterio de Fitero; documentos medievales; cartulario de Fitero. non-corroborated cliché to a certain extent in the case of the archive at Fitero, which has fortunately conserved most of its mediaeval documentation.

Keywords: archives of the monastery of Fitero; mediaeval documents; cartulary of Fitero.

\section{SUMARIO}

1. Vicisitudes de la documentación medieval del monasterio cisterciense de Fitero.- 2. Inventario de la documentación medieval.- 3. Conclusiones.

\section{VICISITUDES DE LA DOCUMENTACIÓN MEDIEVAL DEL MONASTERIO CISTERCIENSE DE FITERO}

La fundación del monasterio de Fitero nos ha sido relatada brevemente por uno de sus protagonistas principales, Fr. Ignacio de Ibero, abad del cenobio entre 1592 y $1612^{2}$. Su Relación de la fundación y antigüedad del monasterio de Santa María la Real de Fitero es un perfecto ejemplo de cómo los mismos documentos del archivo monástico podían resultar apropiados para usos tan dispares como defender el señorío eclesiástico frente a obispos discutidores de su jurisdicción (el de Tarazona), o bien resaltar el Patronato regio (en este caso Felipe II) ${ }^{3}$. Fray Ignacio era persona de elevadas dotes intelectuales y compartía con el obispo pamplonés, Bernardo de Rojas, la afición por la historia. Se apreciaban mutuamente, como lo manifestaba en su Relación $n^{4}$. En el caso del abad, se propuso redactar la crónica de la Orden cisterciense, para lo cual, no dudó en enviar a un monje de su comunidad, fray Bernardo de Villalpando, a la casa madre de Citeaux para rebuscar documentos en su archivo y extraer copias ${ }^{5}$. Tanto el material allegado de Francia como el que encontró buceando en su archivo fiterano le sirvió para escribir sus Exordia Sacri Ordinis Cisterciensis, obra impresa en el propio monasterio en $1606^{6}$.

Estos incipientes viajes literarios, así como la redacción de estas obras historiográficas, nos sitúan en el s. XVII, momento de gran efervescencia intelectual. En Fitero se añadió además la exaltación de San Raimundo, segundo abad y fundador

\footnotetext{
${ }^{2}$ Francisco Fuentes Pascual, Fray Ignacio de Ibero abad de Fitero, "Príncipe de Viana", 19 (1945), pp. 281-294.

${ }^{3}$ AHN, Códices, 371 B, ff. 1-10. Consultable en el portal PARES del Ministerio de Cultura [WWW.pares.mcu.es]

${ }^{4}$ AHN, Códices, 371 B, f. 3.

${ }^{5}$ AHN, Códices, 371 B, f. 2.

${ }^{6}$ Antonio PÉREZ GOYENA, Ensayo de bibliografía navarra desde la creación de la imprenta en Pamplona hasta el año 1910. Pamplona, 1949, t.2, pp. 23-27; Santos GARCÍA LARRAGUETA, La imprenta en los monasterios, en La imprenta en Navarra. Pamplona, 1974, p. 194; Fitero: el legado de un monasterio, en [Exposición], Monasterio de Fitero, Navarra, 26 de abril al 29 de julio de 2007, (organiza, Fundación para la Conservación del Patrimonio Histórico de Navarra; comisario, Ricardo Fernández Gracia), Pamplona, 2007, pp. 264-265.
} 
de la Orden militar de Calatrava ${ }^{7}$. Tampoco resulta casual que la historia fiterana se redactara en el s. XVII cuando el señorío civil y eclesiástico estaba bien consolidado, si bien no faltaron tumultuosas contestaciones de su villa en forma de revueltas y saqueos que también afectaron al archivo ${ }^{8}$. De todos modos estas pérdidas no eran las primeras que sufría el monasterio. Rebuscando en la secular historia del cenobio hay varias menciones de conflictos fronterizos entre los reinos de Navarra y Castilla. Sabemos que en 1334, con motivo de la guerra con Castilla, Miguel Zapata se apoderó del monasterio y del castillo de Tudején por orden del infante Pedro de Aragón y del gobernador de Navarra ${ }^{9}$. La zona sin embargo tuvo muy poca seguridad, hasta que tras la guerra de 1373 de nuevo entre Navarra y Castilla, fructificó la mediación pontificia del cardenal Guido de Bolonia que dictaminó que Fitero pertenecía a Navarra. En 1436 la comunidad debió refugiarse en Tudela durante varios años. Abandonado por sus inquilinos, el monasterio fue saqueado y sus escrituras parcialmente destruidas ${ }^{10}$.

No es extraño que con tanta violencia y anarquía, el archivo monástico quedara deteriorado, hasta el punto de que Fr. Miguel Bautista Ros, el archivero más laborioso del monasterio, dijera en el Tumbo Naranjado de 1634: "muchas de las escrituras que tiene el monasterio en su archivo las a avido y recobrado sacandolas con provisiones y mandatos de la real chancillería de Valladolid y del real Consejo de Navarra, de los archibos de Agreda, Cervera y otras partes"11. Afortunadamente para Fitero estos tribunales ayudaron en repetidas ocasiones a obtener copias de documentos de interés que no se conservaban en el archivo monástico, y que se obtuvieron mediante requerimiento judicial a los alcaldes de las villas próximas en las que el cenobio tenía propiedades, para que autorizaran el traslado de documentos notariales ${ }^{12}$. También se consiguieron copias de los archivos de las escribanías de los propios tribunales ${ }^{13}$, o se solicitaron a otros monasterios ${ }^{14}$.

En la actualidad la documentación fiterana se encuentra repartida entre el Archivo Histórico Nacional (secciones de Clero, Códices y Sigilografía), y el Archivo General de Navarra (Sección Clero, y Códices y Cartularios). Incautada la documentación en 1835 durante la desamortización de Mendizábal, pasó a las oficinas de la Caja de Amortización en Pamplona, precursora de la Delegación de Hacienda estatal, donde estuvo muchos años. Unas remesas se enviaron al Archivo Histórico Nacional de Madrid a finales del s. XIX. Lo que quedó en Navarra permaneció en el archivo de

\footnotetext{
${ }^{7}$ Ricardo FERNÁNDEZ GRACIA, Iconografía de San Raimundo de Fitero, "Príncipe de Viana", 199 (1993), pp. 293-254; R. FERNÁNDEZ GRACIA, Entre la historia, la leyenda y el mito. La imagen de San Raimundo, abad de Fitero y fundador de la Orden militar de Calatrava, en Fitero: el legado de un monasterio, pp. 127-172.

${ }^{8}$ Florencio IDOATE IRAGUI, Rincones de la Historia de Navarra, Pamplona, 1954, t. 1, pp. 235 241. José GoÑ GaZTAMBIDE, Historia del monasterio cisterciense de Fitero, "Príncipe de Viana", 100/101 (1965) p. 306 y José Maria JiMEnO JuRIO, Fitero, Pamplona, 1982, pp. 19-22.

${ }^{9}$ Fray Jerónimo de ÁLAVA, Relación de privilegios concedidos al monasterio y otras escrituras y sucesos acaecidos al dicho monasterio desde su fundación, AHN, Códices, 371 B, versión digitalizada, imagen 17 y ss.; Pilar AzCÁRATE, La guerra de 1335 entre Castilla y Navarra, "Hispania", 49 (1989), pp. 805-840; Íñigo MugueTA MoRENO, Acciones bélicas en Navarra: la frontera de los malhechores (1321-1335), "Príncipe de Viana", 219 (2000), pp. 49-78.

${ }^{10}$ J. GOÑI GAZTAMBIDE, Historia del monasterio, pp. 298-303.

${ }^{11}$ AHN, Códices, 906 B, f. 726v.

${ }^{12}$ AGN, Clero, Fitero, caj. 34400, n 428, f. 40 (Ros, tabla 2, fajo 1, f. 15), 119v, (Ros, tabla 2, fajo 86, f. 55), f. 167v, (Ros, tabla 8, fajo 1, n 11, 18, 29); AHN, Clero, leg. 4896, exp. 8.

${ }^{13}$ AGN, Clero, Fitero, caj. 34400, no 428, f. 96v (Ros, tabla 2, fajo 66, no 41), 125 (Ros, tabla 2, fajo 108, f. 179), 143 (Ros, tabla 3, fajo 12, f. 20); AHN, Clero, leg. 4898.

${ }^{14}$ AGN, Clero, Fitero, caj. 34400, no 428, f. 115 (Ros, tabla 2, fajo 81, n 3, 4).
} 
la Delegación de Hacienda estatal, a cargo del archivero del Cuerpo Facultativo del Estado, hasta 1929 en que la Diputación Foral logró que pasara en calidad de depósito al Archivo General de Navarra, donde permanece. De este modo, el Archivo General de Navarra pasó a conservar una parte cuantitativa y cualitativamente muy rica de los fondos monásticos, entre los que destaca el cartulario medieval de Fitero ${ }^{15}$.

Este corte en la documentación hoy conservada entre Pamplona y Madrid no es cronológico ni obedece a pautas. Sencillamente, el director del Archivo Histórico Nacional, Vicente Vignau, reclamó a los archiveros de las Delegaciones de Hacienda provinciales el envío de documentación preferentemente medieval, y más tarde cuando creyó que todo había sido recibido, la de época moderna. Una vez en su destino se procedió a la separación física entre pergaminos (carpetas), papeles sueltos (legajos) y libros encuadernados. A su vez, algún privilegio con sello pasó a la Sección Sigilografía, y los libros más interesantes en cuanto a su contenido, a la Sección de Códices y Cartularios ${ }^{16}$.

Retrocediendo otra vez en el tiempo, comprobamos que el archivero Miguel Bautista Ros tuvo mucho cuidado en describir en su inventario redactado en 1634, no sólo la documentación real sino también la pontificia, ya que la defensa del señorío monástico era civil pero también eclesiástica ${ }^{17}$. La mayoría de estos pergaminos está a su vez descrita en los inventarios posteriores del s. XVIII (1708 y 1798), con la salvedad de que en esta época, la dificultad de descifrar la escritura y la peculiar datación medieval hizo que los archiveros se sirvieran tanto de los documentos originales como de las copias de tales privilegios que se consiguieron a finales del s. XVII, cuando el Consejo real de Navarra sentenció a favor del monasterio en el largo contencioso que sostuvo con su villa de Fitero a causa de la jurisdicción temporal y eclesiástica ${ }^{18}$. Muchos de los que utilizaron la documentación del monasterio en época moderna cometieron frecuentes errores de reducción de cómputo, descubiertos por Cristina Monterde al elaborar la colección diplomática fiterana ${ }^{19}$.

Nuestra intención es continuar con la identificación y localización de la documentación medieval desde la fecha en que terminó la colección diplomática la Dra. Monterde. Por ello a la hora de seguir la pista de los privilegios inventariados por los archiveros fiteranos en edad moderna (años 1634, 1708 y 1798), tomamos como punto de partida la documentación actualmente conservada en el Archivo General de Nava-

\footnotetext{
${ }^{15}$ Publicado inicialmente por Mariano ARIGITA Y LASA, Colección de documentos inéditos para la Historia de Navarra. Pamplona, 1900; Con más rigor por Cristina MonTERDE AlBIAC, Colección diplomática del monasterio de Fitero (1140-1210, Zaragoza, 1978.

${ }^{16}$ Luis SÁnchez BeldA, Guía del Archivo Histórico Nacional. Madrid, 1985, pp. 33-38; José Maria LACARRA, Guía del Archivo General de Navarra, Madrid, 1953, p. 130; Juan José MARTINENA RuIZ, Guía del Archivo General de Navarra. Pamplona, 1997, pp. 34 y 231; Luis Miguel CRUZ HerRANZ, La Sección de Clero del Archivo Histórico Nacional en II Jornadas Científicas sobre documentación de la Corona de Castilla (s. XIII-XIX), Madrid, 2003, pp. 373-405.

${ }^{17}$ AGN, Clero, Fitero, caj. 34400, no 428, ff. 10-20 (Ros, tabla 1, fajos 3-6).

${ }^{18}$ AGN, Clero, Fitero, caj. 34401, nº 461.

${ }^{19}$ Cristina Monterde AlBIAC, Colección diplomática del monasterio de Fitero, pp. 202-214. La Colección reúne todos los documentos conservados pertenecientes al monasterio y datados entre el s. XII y las dos primeras décadas del XIII, los originales en especial la documentación real y pontificia, así como las piezas eclesiásticas y particulares. Además las copias, incluyendo el análisis del cartulario medieval de la abadía, estableciendo la fiabilidad del mismo. Cada referencia lleva el correspondiente desarrollo de la traditio documental, con mención de los ejemplares que se conservan sobre cada documento, desde su primera elaboración hasta el s. XVIII, incluyendo las versiones copiadas en tumbos e historias de edad moderna, como el Tumbo Naranjado o las Memorias del padre Calatayud. Como todo estudio documental universitario, consta de un capítulo introductorio donde se analizan y presentan las fuentes estudiadas, que abarca las pp. 5-28.
} 
rra y el Archivo Histórico Nacional, cotejando las signaturas antiguas que aparecen al dorso de los documentos con las referencias de dichos inventarios. De esta forma se puede detectar la cantidad de documentación conservada y perdida, para evaluar la situación del archivo monástico hasta la desamortización, y si el cierre e incautación del archivo en el s. XIX supuso un factor decisivo para la pérdida de documentos. La mayoría de las piezas medievales conservadas a partir del s. XIII son originales en pergamino, aunque en numerosas ocasiones hayan perdido sus sellos. Pero al llegar al s. XV y tal vez por las desastrosas consecuencias de la guerra civil navarra a la que no fueron ajenos los monasterios y quienes los regían en esa época, aumenta el número de traslados notariales realizados a requerimiento de los tribunales tanto castellanos como navarros, cuando en la edad moderna el monasterio luchó por recuperar propiedades y derechos contestados por las localidades vecinas.

Hay que advertir que los orígenes del cenobio fiterano han sido controvertidos entre los propios correligionarios de la Orden, provocando pleitos y no poca disputa historiográfica para determinar a quién correspondía la gloria de ser el primero del Císter en Navarra. El motivo de tales debates tiene que ver con el espinoso contencioso de la preferencia de asiento en el brazo eclesiástico de las Cortes de Navarra del periodo moderno, y la reticencia a reconocer que Fitero, que se había incorporado al reino de Navarra en 1373, tuviera prelación sobre La Oliva que hasta entonces había gozado de tal posición. Parece que al monasterio fiterano le cabe el honor de ser el más antiguo del Císter no solo en Navarra sino tal vez de toda España. Aunque sus orígenes no se situaran en la vega de Fitero sino en el monte Yerga, tal y como reconocen los propios historiadores cistercienses en las historias elaboradas a partir del s. XVII. Sin embargo recientemente se ha querido remover el asunto, utilizando como argumento la supuestamente escasa fiabilidad del documento más antiguo de $1140^{20}$. Sin embargo para esta fecha el Emperador ya se había traído de Francia al canciller Hugo y al escriba Giraldo, que son los verdaderos organizadores de la cancillería de Alfonso VII. Por otra parte, del mencionado escriba se conservan más documentos en otros archivos españoles que avalan el carácter genuino y auténtico del documento del archivo fiterano.

El monasterio de Fitero cuenta con un factor que revaloriza enormemente su documentación, y es el de haber conservado el original de la primera dotación de lo que sería la primitiva sede de la Orden cisterciense en el territorio entonces del reino de Castilla. La relación documental que aquí se presenta, recoge la secuencia de documentos medievales en formato de pieza exenta, es decir no correspondiente a copia de cartularios u otros códices diplomáticos, salvo en aquellos casos en que por la importancia de la dotación y a falta de otra referencia, se ha recurrido a la versión del cartulario medieval, del Tumbo naranjado de 1634, o de los inventarios modernos del archivo.

\section{INVENTARIO DE LA DOCUMENTACIÓN MEDIEVAL}

-1140-10-25.- Ribera del Ebro, entre Calahorra y Alfaro

Alfonso VII concede la villa y lugar de Niencebas a la iglesia de Santa María fundada en el monte Yerga por el abad Durando y sus monjes cistercienses.

AGN, Clero, Pergaminos Fitero, leg. 51, no 476. Original/ Invent. 1634, caj. 3, fajo $1 \mathrm{n}^{\circ} 1 / \mathrm{In}-$ vent. 1708. cajón 1 , fajo $1, \mathrm{n}^{\circ} 1 /$ Invent. 1798, Clase $4^{\mathrm{a}}$, fajo único, $\mathrm{n}^{\circ} 6$.

${ }^{20}$ Fitero: el legado de un monasterio, p. 34, nota 25, y p. 180; Serafín OLCOZ YANGUAS, Memorias del monasterio de Fitero de padre Calatayud, (Edición crítica), Pamplona, 2005. 
-1141 , Junio 2

Pedro Tizón y su mujer Doña Toda e hijos donan la heredad que tienen en Niencebas a Raimundo abad de Santa María de Niencebas y a su comunidad.

AGN, Códices, Cartulario Fitero, ff. 55-55v/ El inventario de 1708 indica que en esa época no se conservaba original en el archivo, sino la copia del cartulario medieval y del Tumbo Naranjado, en AHN, Códices, 906 B, nº 132.

$-1141$

Fortún Garceiz y sus hijos donan la heredad que tienen en Niencebas al monasterio de Santa María de ese lugar.

AGN, Códices, Cartulario Fitero, f. 55v. Copiado a su vez en el Tumbo Naranjado, AHN, Códices, $906 \mathrm{~B}, \mathrm{n}^{\circ} 133$.

$-1141$

Fortún López, su mujer Sancha e hijos, donan la heredad que tienen en Niencebas al abad Raimundo de Santa María de Niencebas y su comunidad.

AGN, Códices, Cartulario Fitero, f. 55; AHN, Códices, 906 B, Tumbo Naranjado, no 131.

-1146-10-15.- Niencebas

Alfonso VII dona su serna de Cervera a la iglesia de Santa María de Niencebas y a su abad Raimundo.

AGN, Códices, Cartulario Fitero, ff. 43v-45/ Invent. de 1634, caj. 3, fajo 3, n 43; AGN, Clero, Fitero, caj. 34401, n 461; AGN, Clero, caj. 33859, nº 268. Además AHN, Códices, 906 B, Tumbo Naranjado ${ }^{\circ}$ 114/ Invent. 1708, cajón 1, fajo 70, f. 268.

-1147-09-17.- Citeaux

Eugenio III otorga protección pontificia y confirma a Raimundo abad de Niencebas y a los monjes de su comunidad, la tierra de Niencebas, el lugar de Fitero, el de Oliva y Veruela con sus tierras, granjas diezmos y pastos que les corresponden.

AHN, Clero, carp. 1397. $n^{\circ}$ 8. Original aunque no conserva la bula/ Invent. 1634 caj. 3, fajo 3, $\mathrm{n}^{\mathrm{o}} 1$ / Invent. 1708, cajón 1, fajo $3, \mathrm{n}^{\mathrm{o}} 2 /$ Invent. 1798, Clase $3^{\mathrm{a}}$, fajo $1, \mathrm{n}^{\mathrm{o}} 1$. Dicho documento es expedido en el capítulo general de la Orden cisterciense al que acudió el abad Raimundo.

-1147-09-17.- Citeaux

Eugenio III otorga protección pontificia a Raimundo abad de Yerga y a los monjes de su comunidad instalados en Yerga. Confirma además las propiedades de la tierra de Yerga, el lugar de Fitero y el de Oliva con sus tierras, granjas, diezmos y pastos que les corresponden.

A.OinENART, Notitia utrisque Vasconiae. San Sebastián, 1929, p. 101, según información remitida por fray Jerónimo de Álava, monje historiador de Fitero, pero no aparece en ninguno de los inventarios del archivo fiterano. Citando a Oihenart, lo transcribe J.P. MiGNE, "Eugenii III epistolae et privilegia", en Patrologia latina, t. 180, n 224, col. 1278 y lo extracta P. JAFFE, Regesta pontificum romanorum ab condita ecclesia ad annum post Christum natum 1198. Leipzig, 1885-1888, 9134, p. 47.

-1148-02-06.- Tarazona

Miguel, obispo de Tarazona, exime del pago de diezmos al monasterio de Niencebas por los frutos de sus granjas cultivados por los monjes.

AGN, Clero, Pergaminos Fitero, $n^{\circ} 391$, copia simple/ Invent. 1634 caja. 3, fajo 3, no 37/ Invent. 1708, caj. 1, fajo 3, nº 12/ Invent. 1798, Clase 3, fajo 1, nº 2.

-1148-04-05.- Almazán

Alfonso VII dona al abad Raimundo y su comunidad de la iglesia de Santa María de Niencebas, el monasteriolo de San Bartolomé de Anaguera (Noguera). 
AGN, Clero, Fitero, no 234, f. 11. Copia simple en papel de mediados del s. XVI/ Invent. 1798, clase $4^{\text {a }}$, copias privilegios, fajo único, f. 9 y f. $89 v$. .

AHN, Códices, 906 B, Tumbo Naranjado de Fitero, ff. 426v-427.

-1152-07-09.- Segni

Eugenio III confirma a Raimundo abad de Fitero y a su comunidad, las posesiones del monasterio, es decir "locum in quo ipsum monasterium situm est, Necevas cum decimis et aliis pertinenciis suis, Casam Novam cum decimis et aliis pertinenciis suis, Anaveram cum decimis et aliis pertinenciis suis", y lo recibe bajo la protección pontificia.

AGN, Clero, Pergaminos Fitero, no 391, copia simple/ Invent. 1634, caj. 3, fajo 3, nº 11/ Invent. 1708, cajón 1, fajo 3, no 12/ Invent. 1798, Clase 3, fajo $1 n^{\circ} 4$.

-1153-06-02.- Soria

Alfonso VII confirma al abad Raimundo y los monjes de Santa María de Castellón (de Fitero), el lugar de Niencebas con sus pertenencias, y el realengo de Anegora más la serna situada sobre los baños de Tudején.

AGN, Códices, Cartulario Fitero, ff. 54-55; AHN, Códices, 906 B Tumbo Naranjado, f. 426v; AGN, Clero, Fitero, caj. 34401, n 461, fajo 70, n 269, copia

-1156-08-02.- Calahorra

Sancho III de Castilla toma bajo su protección al abad Raimundo y al monasterio de Castellón (de Fitero), para que su ganado pueda pastar libremente y si se mezcla con ganado de otros propietarios, sea restituido al monasterio.

AHN, Sellos, carp. 1, no 3. Original/ Invent. 1634, caj. 3, fajo 1, nº 5/ Invent. 1708, cajón 1, fajo $1, n^{\circ}$ 5/ Invent. 1798, Clase 4a , fajo único, copias f. 11.

-1157-01.- Tudela

Sancho VI el Sabio de Navarra toma bajo su protección los bienes del monasterio de Castellón (de Fitero) en su reino, manda restituir los bienes robados, definir los pleitos según la declaración de los monjes, autoriza que su ganado paste en el reino y les exime del pago de peajes y portazgos.

AGN, Clero, Pergaminos Fitero, $n^{\circ}$ 219. Original con restos de foramen del que colgó el sello/ Invent. 1634, caj. 3, fajo $1, n^{\circ} 14 /$ Invent. 1708, cajón 1, fajo $1, n^{\circ} 8 /$ Invent.1798, Clase $4^{\mathrm{a}}$, fajo único $\mathrm{n}^{\circ} 2$.

AGN, Clero, Pergaminos Fitero, no 468 , copia de 1294 por el notario público de Tarazona Andrés Pérez Cervera con suscripciones del vicario de Cintruénigo, el notario de la cancillería episcopal turiasonense, y de los notarios de Cascante Andrea de Ponte y Clemente de Aspes/ Invent. 1634 caj. 3 , fajo $1, n^{\circ}$ 4/ Invent. 1708, cajón 1, fajo 1, no $7 /$ Invent. 1798, Clase $4^{\mathrm{a}}$, fajo único copias, $\mathrm{n}^{\circ} 2$.

-1157-04-15.- Toledo

Sancho III de Castilla dona el castillo de Tudején al monasterio de Santa María de Castellón (de Fitero) y a su abad Raimundo.

AHN, Clero, carp 1397, $n^{\circ}$ 10. Original/ Invent. 1634. cajon 3, fajo 1, nº 3/ Invent. 1708, cajón 1 , fajo $1, \mathrm{n}^{\mathrm{o}} 6 /$ Invent. 1798 , Clase $4^{\mathrm{a}}$, fajo único $\mathrm{n}^{\mathrm{o}} 1$.

-1158-01.- Almazán

Sancho III de Castilla dona la villa de Calatrava a la Orden cisterciense y al abad Raimundo de Fitero.

AHN, Órdenes Militares, Calatrava, carp. 418, n 19-r. Original/ Invent. 1634. cajón 3, fajo 1, $\mathrm{n}^{\circ} 35$ / Invent. 1708, cajón 1, fajo 1, no 9/ Invent. 1798, Clase $4^{\text {a }}$, fajo único, privilegios f. 3 y 12 , y en copias f. 4,13 . 
-1162-09-18.- Dol

Alejandro III toma bajo su protección al monasterio de Fitero y a su abad Guillermo, confirma la regla cisterciense y las posesiones del monasterio y le concede exención de diezmos. Prohíbe asimismo que ningún monje salga del convento sin licencia del abad.

AHN, Clero, carp. 1397. Original falto de bula/ Invent. 1634 caj.3, fajo 3, n 25/ Invent. 1708, cajón 1 , fajo $3, n^{\circ} 13$ / Invent. 1798, Clase $3^{\text {a }}$, fajo $1, n^{\circ} 4$.

-1164-11.- Arrarás

Sancho VI de Navarra concede al monasterio de Fitero y a su abad Guillermo el privilegio de no pagar lezdas en Logroño y toda su tierra.

AHN, Clero, carp. 1397, n¹4. Original/ Invent.1634, caj. 3, fajo 1, n 9/ Invent. 1708, cajón 1, fajo $1, n^{\circ} 10 /$ Invent. 1798, Clase, $4^{\text {a }}$ fajo único, $n^{\circ} 5$.

-1168-08-10.- Avia

Alfonso VIII de Castilla confirma al abad Guillermo la donación de Tudején y concede al monasterio las heredades de Añamaza y Castellón, con sus términos, tierras, viñas, prados y pastos. AHN, Clero, carp. 1397, $\mathrm{n}^{\circ} 15$. Original/ Invent. 1634, caj. 3, fajo 1, $\mathrm{n}^{\circ} 2$ y conf. del mismo en el mismo fajo $\mathrm{n}^{\mathrm{o}} 17 /$ Invent. 1708, cajón 1, fajo 1, $\mathrm{n}^{\mathrm{o}} 11$ / Invent. 1798, Clase $4^{\mathrm{a}}$, fajo único, $\mathrm{n}^{\circ} 14$.

-1176-06.- Soria

Alfonso VIII dona la heredad que tenía en Esteras al abad Guillermo y al monasterio de Fitero. Arch. Catedral Sigüenza, R-46. Original.

-1179-04-07.- Letrán

Alejandro III toma bajo su protección al monasterio de Fitero y a su abad Guillermo, confirmando sus posesiones, dispensando el pago de diezmos y prohibiendo edificar otro monasterio a media legua de distancia.

AHN, Clero, carp. 1397, $n^{\circ} 16$. Original/ Invent. 1634, caj. 3, fajo 3, n $25 /$ Invent. 1708, caj. 1 , fajo $3, n^{\circ} 30 /$ Invent. 1798, Clase $3^{\text {a }}$, fajo $1, n^{\circ} 6$ y 7.

-[1181-1182]

Juan de Todadueña dona al monasterio de Fitero la mitad del molino de Cardosa, reservándose el usufructo mientras viva, pero concede a los pastores y yugueros de Fitero que puedan moler libremente los sábados y construir casas en los lugares que se les señale.

AHN, Clero, carp. 1397, $n^{\circ} 18$. Original, carta partida por ABC/ Invent. 1798, Clase $5^{\text {a }}$, fajo único $\mathrm{n}^{\circ} 32$.

-1184-11-26.- Verona

Lucio III prohíbe a los obispos lanzar censuras contra los cistercienses.

AGN, Clero, Fitero, no 234. Copia simple s. XVI/ Invent. 1634, caj. 3, fajo 3, nº 13.

$-1187$

Urbano III concede privilegio a la Orden cisterciense para que sus abades electos en caso de que el ordinario de la diócesis no los quiera bendecir, puedan ser bendecidos por cualquier obispo, no estando obligados a acudir a los sínodos diocesanos.

AGN, Clero, Pergaminos Fitero, $n^{\circ}$ 464. Traslado de 1322 hecho por el notario apostólico Bernardo de Minorisa, y reconocido como válido por fray Jacobo Valls, abad del monasterio de Santes Creus en 1555/ Invent. 1634, caj. 3, fajo 3, no 5/ Invent. 1708, cajón 1, fajo 3, n 6/ Invent. 1798, Clase 3, fajo $1, \mathrm{n}^{\circ} 19$.

$-1188$

Apeo realizado por los concejos de Ágreda, Cervera y S. Pedro de Yanguas siguiendo el mandato de Alfonso VIII de Castilla para deslindar los términos de Tudején y Niencebas. 
AGN, Clero, Pergaminos Fitero, $\mathrm{n}^{\circ}$ 31. Original partido por ABC, con 3 grupos de oculi de los que colgaron sellos/ Invent. 1634, caj. 3, fajo 1, no 27/ Invent. 1708, cajón 3, fajo 1, nº $27 /$ Invent.1798, Jurisdicción temporal, Clase $1^{\mathrm{a}}$, fajo $1, \mathrm{n}^{\circ} 1$.

-1188 fines

Súplica de Rodrigo obispo de Calahorra, al Papa Urbano III en su enfrentamiento con el obispo de Tarazona sobre la pertenencia de Fitero a su diócesis. El calagurritano argumenta que su antecesor, el obispo Sancho, "benedixit in abatem et sui monasterii altare consecravit quod vocatur Necevas. Et nos poster de illo, quia locus erat aridus ut prediximus, ad Fiterium illos tanquam nostros monachos transtulimus. Et usque ad transitum prefati abbatis, predecesor noster et nos in pace illud monasterium possedimus, et monachum nobis et ecclesie nostre fuerunt obedientes". Después el obispo de Tarazona usurpó el monasterio e impidió al calagurritano bendecir a Guillermo, segundo abad de Fitero, que en la fecha del recurso pontificio era abad de Scala Dei. El obispo de Tarazona con hombres armados "venit ad Fiterium et intrans atrium cum furore et impetu, quosdam de monachis verberavit, quosdam vulnerabit, et capras et porcos monachorum duxit in prendam, quia ecclesie Tirasonensi obedire nolebant".

Arch. Catedral Calahorra, transcrito por P. KeHR, Papsturkunden in Spanien. II Navarra und Aragon. Berlín, 1928, nº 166.

-1189-12-02.- Cuenca

Alfonso VIII de Castilla confirma al monasterio de Fitero y a su abad Pedro, todos los privilegios y derechos que concedió su padre al monasterio de Castellón (de Fitero), tomando a sus granjas bajo su protección, eximiéndoles del pago de censos, y dándoles derecho de pastos.

AHN, Clero, carp. 1397, no 17. Original/ Invent. 1634, caj. 3, fajo 1, no 11 y 21/ Invent. 1708, cajón 1, fajo 1, $\mathrm{n}^{\mathrm{o}}$ 12/ Invent. 1798, Clase $4^{\mathrm{a}}$, fajo único f. 10, y copias f. 35.

\section{-[Hacia 1200]}

Inocencio III confirma los privilegios y posesiones del monasterio de Fitero, es decir, "Necebas, Erga, Firgida, Anavora, Rabanera, granjas de Anamaza y Tudelio, molendina de Magania, posesiones in Cintruenico de Tudela et Peralta, possesiones quas habetis in Calagurrensis et Tirassonensis civitatibus, in Puliera, Autol, Corella, Alfaro, molendinum in Cueva, possesiones in villa de Arnero. Domus in Agreda, Araviana et Soria."

AGN, Clero, Fitero, $n^{\circ} 234$, ff. 243-245. Copia realizada a fines del s. XVI. Falto de datación y suscripciones de la curia pontificia. No recogido en ninguno de los inventarios de Edad Moderna, pero en principio no sospechoso porque otros documentos pontificios copiados en dicho legajo, sí figuran en dichos inventarios.

-1211-12-00.- Tudela

Sancho VII el Fuerte de Navarra confirma al monasterio de Fitero, los términos de Tudején, Villa desierta y Niencebas.

AGN, Clero, Pergaminos Fitero nº 223. Copia del notario eclesiástico Pelegrín López de Lusarreta del obispado de Pamplona de 1406 realizado por mandato de la Cámara de Comptos/ Invent. 1708, cajon 1 , fajo $1, \mathrm{n}^{\circ} 13$.

AGN, Clero, Pergaminos Fitero, no 221. Copia de la Cámara de Comptos de 1564 realizada a petición de monasterio/ Invent. 1634, caj. 3, fajo 2, $\mathrm{n}^{\circ} 15 /$ Invent. 1708, caj. 1, fajo 1, $\mathrm{n}^{\circ} 13$ / Invent. 1798, Clase $4^{\mathrm{a}}$, fajo único, f. 18.

-1212-01.- Tarazona

García, obispo de Tarazona, y el cabildo de dicha iglesia asignan al abad Bernardo y al convento de Fitero la iglesia de San Valentín de Tudején.

AGN, Clero, Pergaminos Fitero, $n^{\circ} 233$. Original redactado por el notario episcopal de Tarazona/ Invent. 1798, Clase $4^{\text {a }}$, fajo único, no 109. 
$-1212-08$

Doña Urraca, hija de Español, y sus hijos venden la heredad que tienen en el término de Tudején al abad Maurín y al monasterio de Fitero.

AHN, Clero, carp. 1397, $n^{\circ}$ 19. Original/ Invent. 1708, caj. 1, fajo 2, nº 1/ Invent. 1798, Clase $4^{\text {a }}$, fajo único, copias, f. 130.

-1214-01.- Burgos

Rodrigo Jiménez de Rada, arzobispo de Toledo, dona al monasterio de Fitero y a su abad Guillermo una heredad sita en dicho lugar, que le venía por herencia de su abuelo Pedro Tizón.

AGN, Clero, Pergaminos Fitero, $n^{\circ}$ 123. Original, carta partida por ABC/ Invent. 1634, caj. 3 , fajo $10, n^{\circ} 6 /$ Invent. 1708 , cajon 1 , fajo $1, n^{\circ} 2 /$ Invent. 1798 , Clase 3 , fajo $1, n^{\circ} 9$.

$-1216-05$

Toda López se ofrece a sí misma a la Orden de los Hospitalarios, eligiendo su sepultura en el cementerio de Calchetas y haciendo donación intervivos de distintos inmuebles sitos en Tudela, y a la muerte de su marido de la torre de Valtierra. Dona asimismo al monasterio de Fitero unas casas, pieza de tierra y huerta en la localidad de Valtierra.

AHN, Clero, carp. 1398, $\mathrm{n}^{\circ}$ 1. Original/ Invent. 1708, cajon 1, fajo 2, $\mathrm{n}^{\circ}$ 10/ Invent. 1798, Clase 5 , fajo $1, n^{\circ} 7$.

$-1219-04-20$

Honorio III faculta al abad de Fitero y a los priores de Santa Cruz y de Artajona, para que sentencien en la causa pendiente entre el diácono Pedro Cristóforo y el abad de Leire, sobre los diezmos de la iglesia de Cáseda.

AGN, Clero, Pergaminos Fitero, caj. 4, $\mathrm{n}^{\mathrm{o}}$ 7. Original con sello de plomo.

-1220-04-14.- Cuenca

Fernando III de Castilla concede carta de libertad al monasterio de Fitero, y confirma la concesión de Alfonso VIII para que se les devuelvan las casas y bienes incautados que el monasterio tiene en Castilla.

AGN, Clero, Fitero, nº 234, ff. 80-80v. Copia en papel. / Invent. 1708, caj. 1, fajo 1, nº 11.

-1220-07-11.- Orvieto

Honorio III ordena que ninguna persona sin especial mandato de la Santa Sede pueda dictar excomuniones, suspensiones ni interdictos contra la Orden cisterciense.

AHN, Clero, carp. 1398, $\mathrm{n}^{\circ}$ 2. Vidimus expedido por un oficial del arzobispado de Tarragona, sobre la bula de Honorio III (1220-07-11) que otorga privilegios a los monasterios cistercienses. AHN, Clero, carp. 1398, $n^{\circ}$ 2. Pergamino notarial. No recogido en los inventarios de Edad Moderna.

-1221-02-13.- Letrán

Honorio III, atendiendo la súplica del rey de Navarra, se dirige a los abades de Fitero y Veruela y al prior de Nájera, para que procuren que Arnaldo de Luna y otros particulares de las diócesis de Zaragoza, Tarazona y Calahorra, satisfagan los daños que causaron cuando entraron violentamente en Navarra estando su rey luchando contra los moros.

AGN, Comptos, caj. $4, \mathrm{n}^{\circ}$ 8. Original a falta del sello de plomo.

$-1221-05$

Fernando Zapata concede a su muerte una pieza en Alfaro para el monasterio de Fitero y a su abad Guillermo durante 10 años, devolviéndose a los hijos del testador pasado ese tiempo, aunque si fallecieran sin sucesión quede definitivamente para el monasterio fiterano.

AHN, Clero, carp. 1398, $n^{\circ}$ 3. Original/ Invent. 1708, cajón 1, fajo 2, nº 2/ Tal vez Invent. 1798, Clase $5^{\text {a }}$, fajo único $\mathrm{n}^{\circ} 9$. 
-1222-01-05.- Toledo

Fernando III el Santo autoriza a los moros de su reino para poblar Tudején, castro de los monjes de Fitero.

AGN, Clero, Fitero, $n^{\circ}$ 234. Copia simple en papel/ Invent. 1634, caj. 3, fajo 1, $\mathrm{n}^{\mathrm{o}}$ 18/ Invent. 1708 anuncia estar copiado en el Tumbo Naranjado, f. 418/ Invent. 1798, Clase $4^{\mathrm{a}}$, fajo único, copias n ${ }^{\mathrm{o}} 15$.

$-1227-10-03$

Fernando Zapata otorga testamento cediendo al monasterio de Fitero la heredad que tiene en Cofín, dos mulas ensilladas y enfrenadas, y unas casas en Alfaro, con obligación por parte del cenobio de sufragar los gastos de su entierro.

AHN, Clero, carp. 1398, $n^{\circ}$ 4. Original, carta partida por ABC/ Invent. 1708, cajón 1, fajo 2, $n^{\circ}$ 14/ Invent. 1798, Clase $5^{\mathrm{a}}, \mathrm{n}^{\circ} 3$.

-1228-01-11.- Letrán

Gregorio IX exime a los monasterios cistercienses de abonar ninguna porción al obispo de la diócesis por los donativos que reciban de los fieles.

AHN, Clero, carp. 1398, $n^{\circ}$ 5. Vidimus en pergamino de 1555-03-30/ Invent. 1634, caj. 3, fajo $3, \mathrm{n}^{\mathrm{o}} 27 /$ Invent. 1708, caj. 1, fajo 3, no 25.

-1230-04.- Calahorra

Juan Pérez, obispo de Calahorra, sentencia en la controversia existente entre las parroquias de la diócesis de Calahorra y el monasterio de Fitero sobre funerales.

AGN, Clero, Pergaminos Fitero, $n^{\circ}$ 477. Original, carta partida por ABC/ Invent. 1634, caj. 3 , fajo $3, n^{\circ} 33$ / Invent. 1708, cajón 1, fajo 3, n⿳2 29/ Invent 1798, Clase $3^{\text {a }}$, fajo $1, n^{\circ} 10$.

-[c. 1230]

Fortún Navarro se dona a sí mismo además de unas heredades que tenía en Valdeprado y unas casas en Fitero, favoreciendo al monasterio de Fitero y a su abad Guillermo.

AHN, Clero, carp. 1399, $\mathrm{n}^{\circ}$ 18. Original, carta partida por ABC/ Invent. 1798, Clase $4^{\text {a }}$ fajo único, copias n 127.

$-1231$

Juan, hijo de Pedro Joannes, alcalde del Burgo (de Arnedo), se dona a sí mismo y unas casas más un huerto en el citado lugar, a favor de monasterio de Fitero y su abad Guillermo.

AHN, Clero, carp. 1398, $n^{\circ}$ 6. Original/ Invent. 1708, caj. 1, fajo 2, nº 60 y 61/ Invent. 1798, Clase $4^{\mathrm{a}}$, fajo único, $\mathrm{n}^{\circ} 108$.

-1234-01-08.- Soria

Fernando III el Santo confirma las posesiones del monasterio de Fitero y concede al mismo amparo real.

AHN, Clero, carp. 1398, $\mathrm{n}^{\circ}$ 7. Original, privilegio rodado sin terminar la rueda y carente de sello/ Invent. Ros, caj. 3, fajo 1, no 20/ Invent. 1708, cajón 1, fajo 1, n $15 /$ Invent. 1798 Clase $4^{\mathrm{a}}$, fajo único, $\mathrm{n}^{\circ} 12$.

-1234-07-05

Pedro Garcés de Arróniz dona al monasterio de Fitero unas heredades en Cervera y Andión, con sus collazos y cuanto había heredado en Navarra de García de Cervera.

AHN, Clero, carp. 1398, nº 8. Original/ Invent. 1708, cajón 1, fajo 2, nº 3/ Invent 1798, Clase $5^{\mathrm{a}}$, fajo único, $\mathrm{n}^{\circ} 4$.

-1236-10-17.- Roma

Gregorio IX escribe al obispo de Tarragona y prelados de la diócesis sobre ciertas injurias hechas al abad y monjes de Fitero, para que hagan restituir al monasterio los bienes ilícitamente enajenados. 
AHN, Clero, carp. 1398, $n^{\circ}$ 9. Original/ Invent. Ros, caj. 3, fajo 3, $n^{\circ}$ 6/ Invent. 1708, caj. 1, fajo $3, n^{\circ} 7 /$ Invent. 1798, Clase $3^{\text {a }}$, fajo $1, n^{\circ} 11$.

$-1237-03$

Felicia dona al monasterio de Fitero la propiedad de la mitad de unas casas y medio huerto en El Burgo de Arnedo, y una viña en Valpina, reservándose el usufructo. Condiciona la donación a que sus parientes puedan ejercitar el derecho de retracto, con obligación de compensar al monasterio con cierta cantidad.

AHN, Clero, carp. 1398, $\mathrm{n}^{\circ}$ 10. Original, carta partida por ABC/ Invent. 1708, cajón 1, fajo 2, $\mathrm{n}^{\circ} 4$ / Invent. 1798, Clase $5^{\text {a }}$, fajo único, $\mathrm{n}^{\circ} 5$.

$-1238-01-00$

Teresa se entrega a sí misma y las propiedades que tiene en Alfaro a favor del monasterio de Fitero, cediéndole su abad el usufructo de unas casas, viñas y huerto sitos en dicha villa.

AHN, Clero, carp. 1398, $\mathrm{n}^{\circ}$ 11. Original, carta partida por ABC/ Invent. 1708, cajón 1, fajo 2, $n^{\circ}$ 5/ Invent 1798, Clase $4^{\text {a }}$, fajo único, copias f. 96.

-1244-01-10.- Alcalá de Henares

Guillén Girald canónigo de Toledo y maestrescuela de Tudela, dona al monasterio de Fitero unas casas en Tudela.

AGN, Clero, $n^{\circ} 234$. Copia simple/ Invent 1798, Clase $4^{\text {a }}$, fajo único, copias no 98.

$-1246-11$

Martín de Mosquera cede al monasterio de Fitero y a su abad Bernalt unas casas en Alfaro.

AHN, Clero, carp. 1398, n 12. Original/ Invent. 1634, caj. 3, fajo 11, n 16/ Invent. 1708, cajón 1, fajo 2, nº 6/ Invent. 1798, Clase $5^{\text {a }}$, fajo único, $n^{\circ} 14$.

-1247-05-13.- Lyon

Inocencio IV autoriza a los monjes cistercienses para que puedan ser promovidos a órdenes sagradas sin examen de los obispos.

AHN, Clero, carp. 1398, $n^{\circ}$ 13. Original falto de bula/ Invent. 1634, caj. 3, fajo 3, no 3/ Invent. 1708, cajón 1 , fajo $3, n^{\circ} 5 /$ Invent. 1798, Clase $3^{\text {a }}$, fajo $1, n^{\circ} 13$, y Clase $4^{\text {a }}$, copias f. 28.

-1247-05-13.- Lyon

Inocencio IV concede 40 días de indulgencia a los fieles que visiten la iglesia de Santa María de Fitero el día de su dedicación.

AHN, Clero, carp. 1398, no 14. Original falto de bula/ Invent. 1634, caj. 3, fajo 3, nº 21/ Invent. 1708, caj. 1, fajo $3, \mathrm{n}^{\circ}$ 20/ Invent. 1798, Clase 3, fajo $1, \mathrm{n}^{\circ} 14$.

-1247-05-13.- Lyon

Inocencio IV ordena a los obispos y demás prelados que respeten los privilegios de la Orden del Císter.

AGN, Clero, Fitero, no 234, ff. 43-43v/ Invent. 1634, caj. 3, fajo 3, nº 2/ Invent. 1708, caj. 1, fajo $3, n^{\circ} 3$ / Invent, 1798 , Clase $3^{\text {a }}$, fajo $1, n^{\circ} 12$.

-1247-05-14.- Lyon

Inocencio IV, atendiendo las súplicas del monasterio de Fitero, encarga al obispo de Calahorra que haga restituir al monasterio los bienes usurpados y enajenados ilícitamente.

AHN, Clero, carp. 1398, $n^{\circ}$ 15. Original falto de bula/ Invent. 1634, caj. 3, fajo 3, nº 24/ Invent. 1708, caj. 1, fajo 3, no 23/ Invent. 1798, Clase $3^{\text {a }}$, fajo $1, n^{\circ} 16$.

-1247-05-29.- Lyon

Inocencio IV confirma las posesiones del monasterio de Fitero tomándolo bajo su protección. AHN, Clero, carp. 1398, n $^{\circ}$ 16. Original falto de bula/ Invent. 1634, caj. 3, fajo 3, nº 15/ Invent. 1708, caj. 1, fajo 3, $n^{\circ} 31 /$ Invent. 1798, Clase $3^{\text {a }}$, fajo $1, n^{\circ} 12$. 
-1247-09-18.- Lyon

Inocencio IV encarga al chantre de Calahorra que defienda al monasterio de Fitero de las injustas exacciones de los rectores de Andosilla y Aldaxacar.

AHN, Clero, carp. 1398, $\mathrm{n}^{\circ}$ 17. Original falto de bula/ Invent. 1634, caj. 3, fajo 3, $\mathrm{n}^{\circ}$ 18/ Invent. 1708, caj. 1, fajo 3, $\mathrm{n}^{\circ} 17 /$ Invent. 1798, Clase $3^{\text {a }}$, fajo $1, \mathrm{n}^{\circ} 17$.

$-1248-04-26$

Juan de Vidaurre señor de Cornago, con el consentimiento de su familia, da al monasterio de Fitero y a su abad Bernardo la iglesia de Santa María de Cornago (de Campolapuente), con prohibición de enajenarla. El monasterio se compromete a designar dos monjes para el culto de la iglesia que ofrezcan plegarias por el donante y sus familiares, entre otros, el arzobispo toledano Rodrigo Jiménez de Rada.

AGN, Clero, Fitero, leg. 18, n⿳0 220. Original falto de sello/ Invent. 1634, cajón 3, fajo 10, nº $7 /$ Invent. 1708, cajón 1, fajo 2, no 7/ Invent. 1798, Clase 4a , fajo único no 17.

-1249-09-05.- Lyon

Inocencio IV concede a los monjes profesos de Fitero, que puedan reclamar los bienes muebles o inmuebles que les puedan corresponder por sucesión o cualquier otro título justo, exceptuando de este derecho los bienes feudales.

AGN, Clero, Fitero, $n^{\circ}$ 234. Copia simple/ Invent. 1634, caj. 3, fajo 3, nº 14/ Invent. 1798, Clase $4^{\mathrm{a}}$, fajo único, copias $\mathrm{n}^{\mathrm{o}} 14$, fechándolo en 1250 .

$-1250-06-13$

Martín abad de San Prudencio vende al monasterio de Fitero y a su abad Bernardo, el molino de San Pedro (de Yanguas) por 200 maravedís.

AHN, Clero, carp. 1398, no 18. Original/ Invent. 1634, caj. 3, fajo 11, n²2/ Invent. 1708, cajón 1, fajo 2, no $8 /$ Invent. 1798, Clase $5^{\text {a }}$, fajo único, $n^{\circ} 15$.

$-1252-01$

Juan de Vidaurre, señor de Cornago, otorga testamento disponiendo ser enterrado en el monasterio de Fitero, y cede unas casas en Tudela para una pitanza el día del aniversario de Rodrigo Jiménez de Rada.

AGN Clero, Pergaminos Fitero, leg. 1, no 178. Original con restos de vínculo del que pendió el sello/ Invent. 1634, caj. 3, fajo 10, nº 9/ Invent. 1708, cajón 1, fajo 2, nº 9/ Invent. 1798, Clase $5^{\mathrm{a}}$, fajo único, $\mathrm{n}^{\circ} 1$.

$-1253-04$

Rodrigo Juanes, señor de Cornago y su mujer Teresa González, declaran adeudar al monasterio de Fitero y a su abad Bernardo 540 mrs. como herederos de su padre Juan de Vidaurre, más otros 300 por préstamos hechos por el cenobio, más varios cahíces de grano. A cambio entregan al monasterio una casa y término en el río de Ixea para pagar con sus frutos el capital e intereses que adeudaban.

AHN, Clero, carp. 1398, nº 19. Original falto de sello/ Invent. 1634, caj. 3, fajo 10, no 8/ Invent. 1708, cajón 1, fajo 2, nº 13/ Invent 1798, Clase $5^{\text {a }}$, fajo único, $n^{\circ} 16$.

-1254-01-06.- Arenas

Alfonso X el sabio ordena a los concejos de Ágreda, San Pedro de Yanguas y Cervera que amojonen los términos de Tudején y Niencebas, de acuerdo con los privilegios concedidos al monasterio de Fitero por los reyes de Castilla.

AHN, Clero, carp. 1399, no 1. Original/ Invent. 1634, caj. 3, fajo 1, no 27 y 28/Invent. 1708, cajón 1 , fajo $2, n^{\circ} 17$. 
$-1254-09$

Fernando de Aibar y su mujer María Pérez ceden una pieza de tierra en Alfaro al monasterio de Fitero y a su abad Bernardo.

AHN, Clero, carp. 1399, $\mathrm{n}^{\circ}$ 2. Original/ Invent. 1708, caj. 1, fajo 2, $\mathrm{n}^{\circ}$ 11/ Invent. 1798, tal vez Clase $5^{\text {a }}$, fajo $1, \mathrm{n}^{\circ} 8$.

$-1254-11$

Los concejos de Ágreda, San Pedro de Yanguas y Cervera nombran procuradores para que amojonen sus términos en relación con los de Fitero, cumpliendo el mandato de Alfonso X el Sabio. AGN, Clero, $n^{\circ}$ 234. Copia simple/ Invent. 1634, caj. 3, fajo 2, nº 7/ Invent. 1798 Jurisdicción temporal, Clase $1^{\text {a }}$, fajo $1, \mathrm{n}^{\circ} 3$.

AGN, Clero, Fitero, caj. 33838, n 27. Compulsoria de la Cámara de Castilla de 1660 al concejo de Agreda para sacar un traslado de su archivo.

-1258-04-12.- Valladolid

Alfonso X el Sabio confirma los privilegios de Alfonso VIII y el infante Fernando relativos a la donación del castillo de Tudején.

AHN, Clero, carp. 1402, $n^{\circ}$ 2. Copia auténtica sacada de la Cámara de Comptos en 1560 en virtud de compulsoria del Consejo real de Navarra a petición del monasterio/ Invent. 1634, caj. 3 , fajo $1, n^{\circ} 12$ / Invent. 1708 cajón 1 , fajo $1, n^{\circ} 18 /$ Invent, 1798, Clase $4^{\text {a }}$, fajo único, $n^{\circ} 60$.

-1258-04-12.- Valladolid

Alfonso X el Sabio confirma los privilegios concedidos al monasterio de Fitero por Alfonso VIII (1168-08-10.- Avia) y Fernando III (1220-04-14.-Opta), y ordena la devolución de las casas, granjas, cabañas y ganados prendados en Castilla.

AHN, Clero, carp. 1399, no 3. Privilegio rodado falto de sello./ Invent. 1634, caj. 3, fajo 1, no 11/ Invent. 1708, cajón 1, fajo 1, no 11 / Invent. 1798, Clase $4^{\text {a }}$, fajo único, ${ }^{\circ} 21$.

AGN, Clero, Fitero, $n^{\circ} 224$. Copia del privilegio rodado con la rueda sin terminar, aceptada como válida por el concejo de San Pedro (de Yanguas) que coloca su sello pendiente del que se conservan huellas del foramen, sin exigir la presentación del original que no había traído el convento "por miedo que les podria contescer algun engaño o alguna perdida". Fue presentada por el monasterio en la Corte mayor de Navarra en 1570, en uno de los contenciosos que libró en defensa de sus propiedades.

-1260-03-22.- Alfaro

Alfonso X el Sabio ordena a los concejos de Calahorra, Arnedo, Alfaro, Ágreda, Cervera y Autol que respeten los privilegios concedidos por sus antecesores al monasterio de Fitero, en relación con los términos, aguas y pastos.

AGN, $n^{\circ}$ 234.Copia simple/ Invent. 1798, Clase $4^{\text {a fajo único, copias n }}{ }^{\circ} 39$.

-1266-03-23.- Sevilla

Alfonso X manda al abad y monjes de Fitero poblar Tudején.

AGN, Clero, Fitero, caja 34401, $n^{\circ} 461$, ff. 235-237. Ejecutoria del Consejo de Navarra expedida en 1685 tras ganar el pleito contra la villa sobre la jurisdicción civil y criminal.

-1266-02-25.- Muruzábal

Concordia sobre la posesión de la villa de Muruzábal, establecida por Clemente de Launay, gobernador de Navarra que dirime las diferencias entre Fitero e Iñigo López de Mendoza.

AHN, Clero, carp. 1399, $\mathrm{n}^{\circ}$ 4. Original falto de sello/ Invent 1634, caj. 3, fajo $10 \mathrm{n}^{\circ}$ 5/ Invent. 1708 , cajón $1^{\circ}$, fajo $2, n^{\circ} 18 /$ Invent. 1798 , Clase $4^{\text {a }}$, fajo único, copias n 24.

$-1266-07-01$

Arrendamiento hecho por fray Arnalt, abad de Fitero, de un huerto en Alfaro a Sancho de Pueyo y su mujer Elvira Jiménez, durante 10 años, con un censo de 20 mrs. anuales.

AGN, Clero, Fitero, no 234. Copia simple/ Invent. 1634, caj. 3, fajo 11, nº 21/ Invent. 1798, Clase $4^{a}$, fajo único, copias $n^{\circ} 133$. 
-1266-11-22.- Pamplona

Diferencias entre el monasterio de Fitero e Iñigo López de Mendoza como representante de su mujer Andrequina, acerca del testamento de García López que aunque hizo donación a favor del monasterio de Fitero, otorgó el usufructo vitalicio de la villa de Muruzábal y la serna situada entre Larraga y Andión a favor de la susodicha y de Diego García de Alfaro.

AHN, Clero, carp. 1399, $\mathrm{n}^{\circ}$ 6. Original, carta partida por ABC falta de sello/ Invent. 1634, caj. 3 , fajo $10 \mathrm{n}^{\circ} 1 /$ Invent. 1708, cajon 1, fajo 2, $\mathrm{n}^{\circ} 17$.

$-1266-11-22$

Teobaldo II ratifica la concordia sobre la villa de Muruzábal lograda por su gobernador en Navarra, poniendo fin al desacuerdo entre el monasterio de Fitero e Iñigo López de Mendoza sobre esta villa y la serna situada entre Larraga y Andión.

AHN, Clero, carp. 1399, $\mathrm{n}^{\circ}$ 5/ Original, carta partida por ABC falta de 3 sellos/ Invent. 1634, caj. 3, cajo 10, $n^{\circ} 2 /$ Invent. 1798, Clase $4^{\text {a }}$, fajo único, $n^{\circ} 22$.

-1270-02-20.- Sto. Domingo de la Calzada

Alfonso X el Sabio manda defender al monasterio de Fitero de las agresiones de los concejos de Ágreda, Cervera, Arnedo, Autol, Quel, Calahorra, Alfaro y San Pedro de Yanguas.

AHN, Clero, carp. 1399, $\mathrm{n}^{\circ}$ 7. Original falto de sello/ Invent. 1634, caj. 3, fajo 1, nº 6 .

$-1270-02$

Fray Sancho, granjero de Noguera, cambia por mandato del abad de Fitero a Miguel González, campanero de la iglesia de Calahorra, una pieza de tierra cerca del villar de Noguera a cambio de otras dos en Berdienes de Noguera.

AHN, Clero, carp. 1399, $\mathrm{n}^{\circ}$ 8. Original, carta partida por ABC/ Invent. 1634, caj. 3, fajo 7, $\mathrm{n}^{\circ} 6 /$ Invent. 1708, cajón 1, fajo 2, n⿳0 20/ Invent. 1798, Clase $4^{\mathrm{a}}$, fajo único, copias no 134.

$-1272-11$

Fray Pedro de Alfaro, tallador de Fitero, permuta por mandato del abad de dicho monasterio, tres piezas de tierra en Cintruénigo con Andrés de Fitero, por otra que éste poseía en el mismo término.

AHN, Clero, carp. 1399, $\mathrm{n}^{\circ}$ 9. Original, carta partida por ABC/ / Invent. 1634, caj. 3, fajo 11, $\mathrm{n}^{\circ}$ 29/ Invent. 1708, cajon 1, fajo 2, no 21 / Invent. 1798, Clase $4^{\text {a }}$, fajo único, copias ${ }^{\circ} 135$.

$-1273-03-14$

El deán de Tudela, juez subdelegado del arzobispo de Toledo, y el arcipreste de Valdonsella, subdelegado del arzobispo de Tarragona, ponen al monasterio en posesión de (ilegible).

AHN, Clero, carp. 1399, $\mathrm{n}^{\circ}$ 10. Original.

-1273-09-06

Fray Juan de Tarva y fray Pedro tallador, monjes de Fitero, dejan vitaliciamente a Ferrera hermana del capellán Martín Domínguez, unas casas en Alfaro y otros bienes muebles.

AHN, Clero, Carp.1399, $\mathrm{n}^{\circ}$ 11. Original, carta partida por ABC/ Invent. 1634, caj. 3, fajo 11, $\mathrm{n}^{\circ}$ 27/ Invent. 1708, cajón 1, fajo 2, n⿳⺈ 23/ Invent. 1798, Clase 4a, fajo único, copias n ${ }^{\circ} 136$.

-1273-11-20.- Alfaro

Fray Arnalt, abad de Fitero, y el cabildo de San Miguel de Alfaro llegan a un acuerdo sobre los bienes de los vecinos de Alfaro que se entierran en el monasterio.

AHN, Clero, Fitero, carp. 1399, $\mathrm{n}^{\circ}$ 12. Original, carta partida por ABC/ Invent. 1634, caj. 3, fajo $11, n^{\circ} 31 /$ Invent. 1708, cajón 1, fajo $2, n^{\circ} 62 /$ Invent. 1798, Clase $4^{\text {a }}$, fajo único, copias $\mathrm{n}^{\mathrm{o}} 132$. 
$-1273-12-05$

Fray Arnalt, abad de Fitero, y el convento arriendan a Corbarán de Vidaurre y su mujer Inés Martínez, unos casales y huerto en Calahorra en el barrio de S. Cristóbal, por 100 mrs. anuales de moneda blanca.

AGN, Clero, Fitero, no 234. Copia/ Invent. 1634, caj. 3, fajo 11, nº 19/ Invent. 1708, cajón 1, fajo 2, nº 22/ Invent. 1798, clase $4^{\text {a }}$, fajo único, copias, $n^{\circ} 137$.

-1278-05-05.- Estella

Diego García de Alfaro, hijo de García López que fue señor de Alfaro, confirma al monasterio de Fitero y a su abad la donación de la villa de Muruzábal hecha por su hermano García López, incluida la serna situada entre las villas de Larraga y Andión.

AGN, Clero, Fitero, $n^{\circ} 225$. Original con foramen del que pendieron 2 sellos/ Invent. 1634, caj.

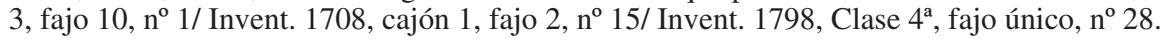

-1285-09-17

Martín Gastón y su mujer Blanca donan al monasterio de Fitero y a su abad Rodrigo unas casas y 4 piezas de tierra en Alfaro.

AHN, Clero, carp. 1399, $\mathrm{n}^{\circ}$ 13. Original/ Invent. 1634, caj. 3, fajo 11, $\mathrm{n}^{\circ}$ 8/ Invent. 1708, caj. 1, fajo $2, n^{\circ} 24 /$ Invent. 1798, Clase $5^{\text {a }}$, fajo único, nº 21.

$-1287-07-10$

Miguel Pérez de Lardero vende a Roy Pérez de Gaceto, abad de Fitero, unas casas, viña y dos piezas de tierra en Tudején, por $600 \mathrm{mrs}$. de los dineros de la guerra.

AHN, Clero, carp. 1399, no 14. Original/ Invent. 1634, caj. 3, fajo 11, n 34/ Invent. 1708, cajón 1 , fajo 2, nº 25/ Invent. 1798, Clase $5^{\mathrm{a}}$, fajo único, nº 23.

-1289-08-07.- Burgos

Sancho IV de Castilla exime al monasterio de Fitero del tributo del yantar que solía dar a los reyes, salvo cuando viniesen personalmente al monasterio.

AHN, Clero, carp. 1399, $\mathrm{n}^{\circ} 15$. Original falto de sello/ Invent. 1634, caj. 3, fajo 1, no $7 /$ Invent. 1708, cajón 1, fajo 2, nº 14/ Invent. 1798, Clase 4ª fajo único, nº 29.

-1294-09-14

Fray Rodrigo de Gaceo, abad de Fitero, y el monasterio dan a censo a Miguel de Cervera, unas heredades en Añamaza, término de Tudején, por 100 mrs.anuales.

AGN, Clero, Pergaminos Fitero, $n^{\circ} 442$ (1). Original, carta partida por ABC, faltan dos sellos/ Invent. 1634, caj. 2, fajo 2/ Invent. 1798, Clase 4a , fajo único, copias, nº 107.

-1296-06-02

Fray Miguel de Pamplona, abad de Fitero, da a censo dos majuelos en Cintruénigo a Johan García y su mujer María Sánchez, por 9 sueldos anuales.

AHN, Clero, carp. 1399, $\mathrm{n}^{\circ}$ 16. Original en carta partida por ABC/ Invent. 1708, cajón 1, fajo 2, no $30 /$ Invent. 1798, Clase 4a , fajo único, copias, nº 106.

-1296-06-19

Juan García y su mujer María Sánchez venden unas casas en Cintruénigo al prior fray Juan Jiménez de Alfaro y al monasterio de Fitero por 300 sueldos.

AHN, Clero, carp. 1399, $n^{\circ}$ 17. Original/ Invent. 1708, caj. 1, fajo 2, no 30/ Invent. 1798, Clase $5^{\text {a }}$, fajo único, $\mathrm{n}^{\mathrm{o}} 24$.

-1299-12-20.- Castrojeriz

Fernando IV confirma el privilegio de Sancho IV (1289-08-07) al monasterio de Fitero relativo al amojonamiento de sus términos de regadío, y acoge bajo su protección a los monjes y bienes del cenobio. 
AGN, Clero, $n^{\circ} 234$, ff. 230-230v, 231-231v, y 235r. Copia simple.

AGN, Clero, Fitero, caj. 34401, no 461, ff. 255-257v. Ejecutoria del Consejo de Navarra de 1685 tras ganar el monasterio un contencioso contra la villa por la jurisdicción civil y eclesiástica/ Invent. 1634, caj. 3, fajo 1, n 13/ Invent. 1708, cajón 1, fajo 1, nº 20/ Invent. 1798, Clase $4^{\mathrm{a}}$, fajo único, $\mathrm{n}^{\circ} 31$.

-1308-07-10.- Burgos

Fernando IV confirma el privilegio de Sancho IV (1289-08-07) dispensando al monasterio de Fitero de pagar yantar, mula ni vaso de plata al merino mayor de Castilla.

AHN, Clero, carp. 1399, n 20. Traslado notarial de 1310/ Invent. 1634, caj. 3, fajo 1, no 33/ Invent. 1708, caj. 1, fajo 1, $\mathrm{n}^{\mathrm{o}}$ 14/ Invent. 1798, Clase $4^{\mathrm{a}}$, fajo único, copias $\mathrm{n}^{\circ} 32$.

-1314-06-25.- Valladolid

Alfonso XI confirma el privilegio de Sancho IV (1289-08-07) relativo a la dispensa de pago de yantar, etc.

AGN, Clero, Fitero, no 228. Copia notarial/ Invent. 1634, caj. 3, fajo 1, nº 10/ Invent. 1798, Clase $4^{\mathrm{a}}$, fajo único, $\mathrm{n}^{\circ} 32$.

-1314-08-17.- Valladolid

Alfonso XI confirma todos los privilegios concedidos al monasterio de Fitero por él y los monarcas antecesores.

AGN, Clero, Pergaminos Fitero, $n^{\circ}$ 229. Original, falto de sello/ Invent. 1634, caj. 3, fajo 1, $\mathrm{n}^{\circ}$ 10/Invent. 1708, cajón 1 , fajo $1, n^{\circ} 21 /$ Invent. 1798 , Clase $4^{\text {a }}$, fajo único, $n^{\circ} 34$.

$-1316-09-24$

Alfonso de Rouvray, gobernador de Navarra, dicta sentencia ejecutoria contra las casas, viñas y piezas que el monasterio de Fitero tenía en Tudela, para pagar lo que adeudaba el monasterio a José Gabay, hijo del judío Juda Gabay.

No localizado, pero referido en Invent. 1708, cajón 1, fajo 2, nº 26.

-1328-11-20.- Valladolid

Alfonso XI renueva su privilegio de 1314 sobre exención del pago de yantares.

AGN, Clero, Pergaminos Fitero, ${ }^{\circ}$ 226. Original, carta plomada falta de sello/ Invent. 1634, caja. 3 , fajo $1, n^{\circ} 19 /$ Invent. 1708 , caj. 1 , fajo $1, n^{\circ} 22 /$ Invent. 1798 , Clase $4^{\text {a }}$, fajo único, no 30.

$-1340$

Benedicto XII, atendiendo a una petición del monasterio de Fitero, ordena al obispo de Calahorra que procure sean restituidos al monasterio los legados testamentarios, diezmos y otros derechos que le corresponden.

No localizado, pero recogido en Invent.1634, fajo 3, n 23/ Invent. 1798, Clase $4^{\mathrm{a}}$ copias, f. 9.

-1342-02-14.- Almazán

Alfonso XI ordena a su baile Juan Martínez averiguar las propiedades entregadas por el monasterio de Fitero a censo, si los que las ocupan lo hacen con derecho por haberlas comprado, o sólo las tienen en usufructo con el objeto de resarcir al cenobio que pasaba por dificultades para cobrar sus censos y rentas. El cumplimiento de la orden se realiza el 9 de Abril.

No localizado, pero referido en Invent. 1708, cajón 1, fajo 2, nº 31.

$-1343$

Clemente VI ordena al sacristán de Tarazona que restituya al monasterio de Fitero los bienes que le tienen ocultados.

No localizado, pero recogido en Invent. 1634, caj. 3, no $17 /$ Invent. 1798, Clase $4^{\text {a }}$ fajo único, copias f. 20. 
$-1347-05-08$

El concejo de Cervera y fray Juan de Menga, abad de Fitero, ajustan un convenio sobre pastos y aguas en el término de Valnueva.

AGN, Clero, Fitero, n 234 . Copia simple/ Invent. 1798, Clase $4^{\text {a }}$, fajo único, copias no 91.

AGN, Clero, Fitero, caj. 33876. Copia del s. XVI por la Cámara de Comptos a petición del monasterio/ Invent. 1798 , clase $5^{\text {a }}$, fajo $2, n^{\circ} 1$.

$-1350$

Ordenanzas de la villa de Cervera y el monasterio de Fitero con referencia a la granja de Valnueva.

AGN, Clero, Fitero, caj. 33851, no 188, ff. 6-8. Copia simple/ Invent. 1798, Clase $5^{\text {a }}$, fajo 2 , $\mathrm{n}^{\mathrm{o}} 3$.

-1362-01-11.- Tudela

Carlos II de Navarra exime a los clérigos, nobles, hidalgos y buenas villas de pagar la ayuda concedida a la corona durante 5 años de un dinero sobre 20 en las compraventas.

AGN, Clero, Pergaminos Fitero, $n^{\circ} 231$. Original/ Invent. 1634, caj. 3, fajo 1, nº 5/ Invent. 1708, cajón 1 , fajo 2 , nº $32 /$ Invent. 1798, Clase $4^{\mathrm{a}}$, fajo único, $\mathrm{n}^{\circ} 37$.

-1366-05-08.- Cervera

Pedro Sánchez de Angulo otorga el agua del río Ixea a fray García de Cervera, abad de Fitero. AHN, Clero, carp. 1402, $n^{\circ} 1$. Copia por compulsoria del Consejo de Navarra de 1560 a petición del monasterio/ Invent. 1708, cajón 1, fajo 1, nº 26/ Invent. 1798, Clase 4a fajo único, nº 41.

-1373-10-03.- Tudela

Declaración del legado papal cardenal Guido, obispo Portuense y de Santa Rufina, de que Fitero corresponde a Navarra.

AGN, Clero, Fitero, caja 33855, no 230. Copia simple / Invent. 1798, Clase $4^{\text {a }}$, fajo único, $n^{\circ} 35$. Hay copia del s. XVII en caj. 33955, nº 230. Copia simple/ Invent. 1798, Clase $4^{a}$ fajo único no 39 .

-1374-04-28.- Olite

Carlos II de Navarra ordena poner bajo autoridad real el castillo de Tudején tal y como se estableció en la concordia lograda con Castilla por el cardenal Guido recibiendo homenaje y vasallaje del abad y convento de Fitero.

AGN, Clero, Pergaminos Fitero, $n^{\circ}$ 238. Copia de la Cámara de Comptos a petición del monasterio en 1560/ Invent. 1634, fajo 3, n $\mathrm{n}^{\circ}$ 34/ Invent. 1708, cajón 1, fajo 1, n 24 / Invent. 1798, Clase $4^{\mathrm{a}}$, fajo único, $\mathrm{n}^{\circ} 40$.

-1376-12-11.- Logroño

Acuerdo de paz entre Castilla y Navarra con el establecimiento de los límites entre Cintruénigo, Corella y Alfaro, y la forma de repartir las aguas de riego.

AGN, Clero, Pergaminos Fitero, $n^{\circ}$ 277. Traslado notarial de 1511/ Invent. 1634, caj. 3, fajo 2, $\mathrm{n}^{\mathrm{o}} 11 /$ Invent.1708, cajón 1, fajo 2, $\mathrm{n}^{\mathrm{o}} 49$ / Invent. 1798, Clase $6^{\mathrm{a}}$, fajo $1, \mathrm{n}^{\mathrm{o}} 8$.

$-1380-12-08$

El concejo de Alfaro, tras la sentencia judicial ganada por el monasterio de Fitero ante los tribunales de Navarra, se compromete a pagar 2.000 mrs. al monasterio en compensación por los daños causados en la presa de Valdebaños.

AGN, Clero, Pergaminos Fitero, $n^{\circ} 238$. Traslado hecho por la Cámara de Comptos por mandamiento real, en 1560/ Invent. 1634, caj. 3, fajo 2, nº 13/ Invent. 1708, cajón 1, fajo 2, n ${ }^{\circ}$ 4/ Invent. 1798, Clase $4^{\mathrm{a}}$, fajo único, copias $\mathrm{n}^{\circ} 53$. 
$-1385$

Amojonamiento entre el monasterio de Fitero y sus facerías, y la villa de Cervera.

AGN, Clero, Fitero, caj. 33836. Copia/ Invent. 1798, Jurisdicción temporal, clase $1^{\text {a }}$, fajo $1, \mathrm{n}^{\circ} 4$. AGN, Clero, Fitero, caj. 33867. Copia del s. XVI/ Invent. 1798, Clase 5a , fajo 2, no 1.

-1403-03-07.- Cervera

Concordia entre Cervera y Tudela sobre ganados.

AGN, Clero, Fitero, caj. 33851, nº 190. Copia/ Invent. 1798, Clase 5a, fajo 2, nº 4.

-1406-05-06

Información del alcalde de Ocón ante el adelantado de Castilla sobre los derechos del monasterio del Fitero para que su granjero pueda cortar leña y pastar en los términos de dicha villa. No localizado pero recogido en Invent. 1708, cajón 1, fajo 2, nº 37.

-1410-01-05.- Fitero

Fray Juan de Anyón, abad del monasterio de Fitero, da a censo unas piezas de tierra en la Portaza a varios vecinos de Fitero para que cultiven hortalizas.

AGN, Clero, Pergaminos Fitero, $n^{\circ} 442$ (5), 443, y 445. Doc. notarial de Miguel del Río/ Invent. 1634, caj. 2, fajo $1, n^{\circ} 5,6 /$ Invent. 1798, Clase $4^{\text {a }}$, fajo único, copias no 139.

-1410-09-08.- Fitero

Fray Beltrán de Falces, abad de Fitero, da a censo una tierra en la Portaza, al cuarto, diezmo y primicia.

AGN, Clero, Pergaminos Fitero, $n^{\circ} 442$ (5). Doc. notarial de Miguel del Río/ Invent. 1634, caj. 2 , fajo $1, \mathrm{n}^{\circ} 7 /$ Invent. 1798, Clase $4^{\text {a }}$, fajo único, copias n 140.

-1414-03-27.- Cervera

Arbitraje de Carlos de Arellano, señor de Cameros y Cervera, sobre disensiones entre Fitero y Cervera sobre la presa de los monjes y su acequia, el pasto en la serna del Emperador, Valdebaño y Añamaza.

AGN, Clero, Fitero, caj. 33851, nº 188, ff. 19v-27. Copia simple presentada por el monasterio en la Chancillería de Valladolid en 1575/ Invent. 1798, Clase $5^{\mathrm{a}}$, fajo 2, $\mathrm{n}^{\mathrm{o}} 3$

-1416-12-07.- Olite

Carlos III de Navarra y el tribunal de la Cort sentencian a favor del monasterio de Fitero en el contencioso planteado por la villa de Cintruénigo sobre aguas de riego y yerbas de Añamaza.

AGN, Clero, Pergaminos Fitero, $n^{\circ} 287$. Original con restos de vínculo del que pendió el sello/ Invent. 1708. cajón 1 , fajo $1, n^{\circ} 27 /$ Invent. 1798, Clase $6^{\text {a }}$, fajo $1, n^{\circ} 3$.

AGN, Clero, Pergaminos Fitero, no 278/ Invent. 1634, fajo 2, n 9 / Invent. 1708, cajón 1, fajo $2, n^{\circ} 50 /$ Invent. 1798, Cintruénigo Clase $6^{\mathrm{a}}$, fajo $1^{\circ}, \mathrm{n}^{\circ} 9$. Hay además una sentencia de la Cort de Navarra de 1516-03-01.- Pamplona, ratificando a petición del abad Martín de Egüés la pronunciada en 1416-02-07.- Olite

-1417-04-30.- Olite

Carlos III de Navarra otorga al monasterio de Fitero exención del pago de cuarteles.

AGN, Comptos, caj.1 116, nº 61, 2(1). Original/ Invent. 1708, cajón 1, fajo 1, nº 27.

-1417-12-08.- Olite

Carlos III hace merced a la villa de Cintruénigo en compensación por el esfuerzo realizado en la fortificación de sus murallas, y atendiendo a la petición de Tudela que avala tales propósitos. Les perdona las 300 libras en que habían sido condenados por haberse llevado violentamente ganados de monasterio de Fitero, incumpliendo los términos de la salvaguarda real al cenobio. AGN, Comptos, caj. 116, nº 94, 3. Original. 
-1418-12-08

García Fernández y Sancho Martínez procuradores de la villa de Alfaro, se comprometen en cumplimiento de las órdenes del rey de Castilla por la querella presentada por el monasterio ante los tribunales navarros, a pagar los $2.000 \mathrm{mrs}$. anuales a que fueron condenados para reparar los daños causados por la rotura de la presa de Valdebaños.

AGN, Clero, Pergaminos Fitero, ${ }^{\circ}$ 261. Copia sacada por la Cámara de Comptos en 1560 a petición del monasterio/ Invent. 1634, cajón 3, fajo 2, no 13 / Invent. 1708, cajón 1, fajo 2, nº 54/ Invent. 1798, Clase $5^{\mathrm{a}}$, fajo $1, \mathrm{n}^{\mathrm{o}} 2$.

-1423-08-14.- Tudela

Sancho Gil de Calchetas y su mujer Juana Jiménez de Gumiel venden al abad Fernando de Sarasa una casa en Tudela por 125 florines de oro.

No localizado, pero referenciado en Invent. 1708, cajón 1, fajo 2, no 34 y 35/ Invent. 1798, Clase $4^{a}$, fajo único, copias n 141.

-1426-03-26.- Fitero

Fray Fernando de Sarasa, abad de Fitero, da a censo unas tierras a Gil Gómez y su mujer Pascuala Jiménez, labradores.

AGN, Clero, Pergaminos Fitero, $n^{\circ}$ 444. Original elaborado por Gonzalo Fernández, notario público de Corella./ Invent. 1634, caj. 2, fajo $1 /$ Invent. 1798, Clase $4^{a}$, fajo único, copias, tal vez $\mathrm{n}^{\circ} 143$.

-1428-05-19.- Simancas

Juan II de Navarra confirma los privilegios de Fitero.

No localizado, pero recogido en Invent. 1708, caj. 1, privilegios, fajo único no $36 \mathrm{y} \operatorname{copias~}^{\circ} 38$.

$-1433$

Sentencia de Juan II de Castilla tras el informe de los diputados de los reyes de Castilla, Navarra y Aragón para tratar el tema de los términos que dividen dichos reinos, corroborando los mojones entre Alfaro, Tudela, Corella y Fitero.

AGN, Clero, Fitero, caja 33836, no 28 . Traslado sacado por orden del Consejo de Navarra en 1569, a petición del monasterio/ Invent 1708, cajón 1, fajo 1, nº 71/ Invent. 1798, jurisdicción temporal, Clase $1^{\mathrm{a}}$, fajo $1, \mathrm{n}^{\circ} 5$.

-1437-08-24.- Corella

Gonzalo Cervera, vecino de Corella, vende un solar en el barrio de la Puent de esta localidad, a Diego de San Pedro, vecino de Corella.

AGN Clero, Pergaminos Fitero, $n^{\circ}$ 479/ Original elaborado por el notario Pero Lorenz de Corella/ Invent. 1634, caj. 3, fajo 11, n 25/ Invent. 1708, cajón 1, fajo 2, n 40 / Invent. 1798, Clase $5^{\text {a }}$, fajo único, $\mathrm{n}^{\circ} 30$.

-1439-06-17.- Olite

Juan II y Blanca de Navarra eximen del pago de cuarteles al monasterio de Fitero. Suscrito por el Príncipe de Viana por encontrarse su madre en mal estado de salud para realizar la suscripción.

AGN, Comptos, caj. 143, nº 29,4. Vidimus del secretario J. de Jaso realizado al día siguiente 18-06-1439.

-1439-10-15.- Olite

Juan II y Blanca de Navarra dictan sentencia para que la villa de Corella devuelva las 500 cabezas de ganado que había prendado al monasterio.

AGN, Clero, Fitero, caja 33855, nº 239. Copia del s. XVI/ Invent. 1634, caja 4, fajo 1. 
-1444-02-21.-Fitero

Juan de Peralta, abad de Fitero, da a censo las rentas de la granja de Rabanera y las tierra de S. Pedro de Yanguas, por 112 florines anuales.

AHN, Clero, carp. 1401, $\mathrm{n}^{\circ}$ 1. Doc. notarial de Per Oliva, escribano de Cintruénigo/ Invent. 1634, caj. 3, fajo 4, no 23/ Invent. 1798, Clase $5^{\text {a }}$, fajo único nº 31.

-1444-09-15.- Pamplona

Carlos, príncipe de Viana, exige al abad y monjes de Fitero, la prestación de pleito homenaje por el castillo de Tudején.

AGN, Comptos, caj. 151, nº 14. Vïdimus del secretario S. de Munárriz realizado en Sangüesa el 20-09-1445.

-1445-12-05.- Sangüesa

Carlos, príncipe de Viana, concede salvaguarda al monasterio de Fitero.

AHN, Clero, carp. 1401, $n^{\circ}$ 2. Original/ Invent. 1634, caj. 3, fajo 1, nº 26/ Invent. 1708, cajón 1 , fajo $1, n^{\circ} 29 /$ Invent. 1798 , Clase $4^{\text {a }}$, fajo único, no 46.

-1446-09-30.- Fitero

Juan de Peralta, abad de Fitero, vende a Juan de Luna, señor de Cornago, la iglesia de Santa María de Campolapuente por 320 florines de oro, debido a la gran necesidad en que se encontraba el monasterio fiterano.

AGN, Clero, caj. 33891, n 415. Copia simple de Juan Sánchez de Cornago, notario de Corella.

$-1454$

Sentencia arbitraria de las diferencias entre Fitero y Cervera por la presa del río Yxea.

AGN, Clero, Fitero, caj. 33867, n 322. Copia del s. XVI/ Invent. 1798, Clase 5a, Fajo 2, no 7.

-1456-09-20.- Tudela

Convenios entre el monasterio de Fitero, la ciudad de Tudela y villa de Corella, autorizando al monasterio a pastar en los montes de Cierzo con 500 cabezas de ganado además de las 1.000 que ya tenía.

AGN, Clero, Fitero, caj. 33903, no 471. Copia notarial del notario de Tudela Juan Martínez de Cabanillas con autorización de los reyes Albret de 1483 de utilizar los protocolos de su antecesor en la notaría para realizarlo/ Invent. 1798, jurisdicción temporal, Clase $4^{\mathrm{a}}$, fajo 1, nº 1, 2.

-1460-05-02.- Calahorra

El deán de Calahorra, juez conservador apostólico diputado por la Sede Apostólica para la Orden del Císter, sentencia definitivamente contra Cintruénigo y el sacristán de Tarazona, adjudicando a Fitero el término de Valverde, sus montes y diezmos.

AGN, Clero, Fitero, caj. 33860, n 274 . Copia/ Invent. 1798, Clase $6^{\text {a }}$, fajo $1, n^{\circ} 5$.

-1461-03-06.- Monasterio de La Oliva

Patente de fray Imberto, abad de Morimond en la diócesis de Lyon, con autoridad del capítulo general cisterciense perdonando la apostasía de fray Fernando, sacerdote hijo de la casa de Fitero, reintegrándole en las órdenes y oficios del Císter, dándole voz y voto para actuar en lo sucesivo como fraile cisterciense.

AHN, Clero, carp. 1401, $n^{\circ}$ 3. Original/ Invent. 1634, caj. 3, fajo 4, no 29/ Invent. 1798, Clase $3^{\mathrm{a}}$, fajo $1,{ }^{\circ} \mathrm{n}^{\mathrm{o}} 26$.

-1465-09-07.- Fitero

Pierres de Peralta, mariscal de Navarra, llega a un acuerdo con el abad Miguel de Magallón y el monasterio de Fitero, permutando el castillo de Turujén a cambio de un censo de 40 cahíces de trigo anuales sobre el molino de Santacara. 
AGN, Clero, Fitero, caj. 33891, no 415. Copia de 1544 por Juan Martínez de Azpíroz notario de Ablitas/ Invent 1798, Clase $5^{\text {a }}$, fajo único, nº 35.

-1465-11-15.- El real frente al castillo de Amposta

Juan II de Navarra concede franqueza de cuarteles al monasterio de Fitero

AHN, Clero, carp. 1401, $n^{\circ}$ 4. Original/ Invent. 1634, caj. 1, fajo 1, $n^{\circ}$ 30/ Invent. 1798, Clase $4^{\mathrm{a}}$, fajo único, $\mathrm{n}^{\mathrm{o}} 47$.

-1466-01-17.- Fitero

Fray Miguel de Magallón, abad de Fitero, entrega a censo a Pelayo, vecino de la localidad, dos piezas de tierra, una al $4^{\circ}$ y otra al $5^{\circ}$.

AGN, Clero, Pergaminos Fitero, $n^{\circ} 442$ (4). Doc. notarial de Per Oliva menor de días/ Invent. 1634, caj. 2, faj. 1/ Invent. 1798, Clase $4^{\text {a }}$, fajo único, $n^{\circ} 148$.

-1469-04-15.- Tudela

Sentencia arbitraria entre el monasterio de Fitero y el cabildo de Tudela sobre los 15 corderos de ventaja que tiene el monasterio.

AGN, Clero, Fitero, caj. 33856, $n^{\circ}$ 243. Es copia del notario Fernando de Andosilla de 1511, al que los reyes Albret autorizan en 1496 para usar los protocolos de su antecesor en el cargo/ Invent. 1634, caj. 3 , fajo 2, no 4 / Invent. 1798, Clase $4^{\mathrm{a}}$, fajo único, $\mathrm{n}^{\circ} 1$.

-1474-06-04

Mateo de Peña, auditor en la causa promovida por el monasterio de Fitero, emite una citación e inhibición contra el abad de San Prudencio sobre la granja de Noguera (o Anaguera).

AHN, Clero, carp. 1401, no 5 y 6. Original del notario apostólico/ Invent. 1634, caj. 1, fajo 2, $n^{\circ} 43$ / Invent. 1708, cajón 1, fajo 2, no 43 y 44/ Invent.1798, Clase 3a , fajo 1, no 27 y 28.

-1477-03-14.- Fitero

Ratificación al abad Gonzalo de Esplugues y al monasterio de Fitero, con licencia del Papa Sixto IV y su Nuncio en España, de la venta realizada en 1446 por fray Juan de Peralta de la iglesia de Santa María de Campolapuente en Cornago, a Juan de Luna señor de dicha localidad, el cual había entregado dicha iglesia a la Orden franciscana.

AGN, Clero, caj. 33891, n 415. Copia simple de Juan Sánchez de Cornago, notario de Corella.

-1480-05-11.- Roma

Sixto IV, por renuncia de la abadía que hizo Gonzalo de Esplugues, nombra a Miguel de Peralta como abad de Fitero.

No localizado, pero recogido en Invent. 1708, caj. 1, fajo 6, $\mathrm{n}^{\circ} 9$.

-1481-07-22.- Valladolid

Fernando e Isabel de Castilla confirman los privilegios otorgados al monasterio de Fitero por sus predecesores, que se insertan (entre ellos el de 1140 al abad Durando instalado en Yerga). Entre otros documentos se confirma el apeamiento de 1254 que delimita los términos de Fitero con los concejos de Ágreda, S. Pedro de Yanguas y Cervera.

AHN, Clero, carp. 1401, $\mathrm{n}^{\circ}$ 7. Cuaderno de pergamino que tuvo en su momento validación con sello de plomo. Original de cancillería basado en el traslado de documentos hecho en Fitero en 1477/ Invent. 1634, caj. 1, fajo 1, n 34/ Invent. 1708, cajón 1, fajo 1, nº 25/ Invent. 1798, Clase $4^{\mathrm{a}}$, privilegios fajo único, $\mathrm{n}^{\mathrm{o}} 56$.

AGN, Clero, Fitero, caj. 33856, nº 247/ Invent. 1798, Clase 4a fajo único, no 49.

-1482-01-30.- Olite

Francisco Febo, rey de Navarra, concede salvaguarda al monasterio de Fitero.

AHN, Clero, carp. 1401, n 9. Original/ Invent. 1634, caj. 3, fajo 1, n² 22/ Invent.1 1708, cajón 1, fajo $1, n^{\circ} 29 /$ Invent. 1798, Clase $4^{\text {a }}$, fajo único n ${ }^{\circ} 53$. 
$-1482-09-26$

Privilegio de Sixto IV sobre décimas.

AHN, Códices 906 B, Tumbo Naranjado, ff. 390v-391r/ Invent. 1634, caj. 3, fajo 3, no 8, 16 y 20 (traslado)/ Invent. 1708, caj. 1, fajo 3, nº 19.

-1483-05-11.- Tudela

Juan de Rada, vecino de Tudela, vende al monasterio de Fitero unas casas en Tudela, en el barrio de Santa María..

AHN, Clero, carp. 1401. no 10. Doc. notarial de Pedro de ?, escribano de Tudela/ Invent. 1634, caj. 3 , fajo $11, n^{\circ} 1 /$ Invent. 1798, Clase $5^{\text {a }}$, fajo único, $n^{\circ} 41$.

-1483-09-18.- Sto. Domingo de la Calzada

Fernando e Isabel de Castilla confirman a Pedro de Egués, abad de Fitero, la propiedad de la villa de Niencebas en contra de las pretensiones de Alfaro.

AHN, Clero, carp. 1401, $\mathrm{n}^{\circ}$ 8. Cuaderno que recoge el traslado de documentos obrantes en el archivo monasterio, recibido en la Curia decanal de Tudela en 1504-05-11, y presentado en la Cort de Navarra en 1575/ Invent. 1634, caj. 1 , fajo ${ }^{\circ}$, $n^{\circ} 34 /$ Invent. 1798 , Clase $4^{\text {a }}$, fajo único, $\mathrm{n}^{\mathrm{o}} 56$.

AGN, Clero, Fitero, caj. 33851, n 187. Copia del s. XVI/ Invent. 1708, cajón 1, fajo 1, nº 34/ Invent. 1798, Clase $5^{\text {a }}$, fajo $9, \mathrm{n}^{\circ} 1$.

-1484.- Cintruénigo

Concordia con Alfaro sobre la granja de Niencebas.

AGN, Clero, Fitero, caj. 33851, no 190/ Invent. 1798, Clase $5^{\text {a }}$, fajo 9, no 4 y 5.

$-1485$

Información en la causa planteada en el Consejo de Castilla por el monasterio de Fitero contra Alfaro sobre los términos de Niencebas.

AGN, Clero, Fitero, caj. 33853, n 205/ Invent. 1798, Clase $5^{\text {a }}$, fajo 9, $\mathrm{n}^{\circ} 7$.

-1487-05-01.- Fitero

El abad Miguel de Peralta concede a los vecinos de Cintruénigo agua para regar sus frutales durante los cinco primeros días de mayo.

AGN, Clero, Pergaminos Fitero, $n^{\circ}$ 276. Es copia notarial hecha a petición del abad Martín de Egüés en 1511, y autorizada por los reyes Juan y Catalina de Albret al notario de Tudela Pedro López de Sangüesa, para sacarla de los protocolos de su antecesor en la notaría/ Invent. Ros. Caj. 5, fajo 17, $\mathrm{n}^{\circ} 1 /$ Invent. 1798, Clase $4^{\mathrm{a}}$, fajo único, copias $\mathrm{n}^{\circ} 151$.

-1487-08-30.- Roma

Inocencio VIII confirma los privilegios de la Orden cisterciense.

No localizado, pero recogido en Invent. 1634, caj. 3, no 19/ Invent. 1708, caj. 1, fajo 3, no 21.

-1489-08-13.- Roma

Inocencio VIII ampara a la Orden del Císter para que no pueda ser visitada por nadie más que por sus visitadores regulares. Además exime a sus vasallos, renteros y granjeros de toda jurisdicción episcopal.

No localizado, pero recogido en Invent. 1634, fajo 3, no 22/ Invent. 1708, caj. 1, fajo 3, nº 28.

$-1489$

Rolde de poderes de los autos y sentencias que se hicieron sobre lo posesorio de la granja y términos de Niencebas en el proceso del monasterio de Fitero contra Alfaro.

AGN, Clero, Fitero, caj. 33853, n ${ }^{\circ}$ 206. Copia del s. XVI/ Invent. 1798, Clase 5a , fajo 9, no 8. 
-1490-05-01.- Fitero

Martín de Egüés, abad de Fitero, por hacer caridad a la villa de Cintruénigo, otorga cinco días de riego salvo para regar linares, de las aguas del río Piedra a su paso por la localidad.

AGN, Clero, Pergaminos Fitero, $n^{\circ}$ 279. Traslado sacado por el notario Fernando de Andosilla en 1511 / Invent. 1634. cajon 2, fajo 7, n 8 / Invent. 1708, cajón 1, fajo 2, no 48/ Invent. 1798, Clase $6^{\mathrm{a}}$, fajo $1, \mathrm{n}^{\mathrm{o}} 7$.

-1493-09-18.- Sto. Domingo de la Calzada

Comisión de los Reyes Católicos para que los vecinos de Alfaro declaren lo que saben sobre la granja de Niencebas, sobre la que el monasterio de Fitero ha pedido justicia en el Consejo de Castilla.

AGN, Clero, caj. 33851, no 190, ff. 6-8v/ Invent. 1634, caj. 4, fajo 2,/ Invent. 1798, Clase $5^{\text {a }}$, fajo $2, n^{\circ} 4$.

-1495-08-16.- Fitero

Fray Miguel de Peralta, abad de Fitero, da a censo una pieza de tierra a Antón de Munilla, portero real y vecino de Tudela, para hacer un batán en Fitero.

AGN, Clero, Fitero, $n^{\circ} 442$ (6). Orig. documento notarial de Pedro López de Sangüesa vecino de Tudela/ Invent 1634, caj. 2, fajo 1, fol. 7/ Invent. 1798, Clase 4a fajo único, copias no 153.

-1495-12-25.- Olite

Juan II y Catalina de Albret ordenan al notario Fernando de Andosilla, receptor de los protocolos notariales de Fitero, expedir las copias necesarias solicitadas por el abad fiterano. Entre ellas se encuentra la referente a la donación de cinco días de riego de las aguas del río Piedra a favor de la villa de Cintruénigo.

AGN, Clero, Pergaminos Fitero, no 276. Traslado de Fernando de Andosilla de 1511/ Invent. 1634, caj. 4, fajo 17, n⿳亠丷厂 1/ Invent. 1708, cajón 1, fajo 2, n⿳⺈ 48.

$-1496$

Comparanzas con Cervera sobre la presa, sacapeños y prendar aves.

AGN, Clero, Fitero, caj. 33851, no 190. Copia simple/ Invent. 1798, Clase $5^{\text {a }}$, fajo 2, n $^{\circ} 8$.

-1498-02-26.- Cervera

Comparanzas sobre cotos y prendas de ganado mayor y menor, hechas entre el monasterio de Fitero y la villa de Cervera.

AGN, Clero, caj. 33851, n 193. Copia simple/ Invent. 1798, Clase 5 a fajo 2, nº 9.

-1501-01-16.- Roma

Rescripto de Alejandro VI a instancia del abad de Fitero sobre la granja de S. Bartolomé de Noguera.

AHN, Clero, carp. 1401, no 11. Original/ Invent. 1634, caj. 3, fajo 7, n 4/ Invent.1708, cajón 1, fajo $2, n^{\circ} 51 /$ Invent 1798 , Clase $3^{\mathrm{a}}$, fajo $1, \mathrm{n}^{\mathrm{o}} 35$.

-1504-06-08

Bula de Julio II a Martín de Egüés, abad de Fitero, imponiendo censuras eclesiásticas contra quienes no pagan los diezmos debidos al monasterio.

AHN, Clero, carp. 1401, $\mathrm{n}^{\circ} 12$. Original/ Invent. 1634, caj. 3, fajo,3, $\mathrm{n}^{\circ} 28 /$ Invent. 1708, caj. 1 , cajón $3, n^{\circ} 26 /$ Invent. 1798, Clase $3^{\mathrm{a}}$, fajo $1, \mathrm{n}^{\circ} 36$.

-1504-12-15.- Zaragoza

Mandato del juez conservador de Calahorra para que se ejecute cierta sentencia contra particulares de Alfaro por daños causados años atrás en las presas y baños del monasterio de Fitero en Valdebaños.

AGN, Clero, Fitero, caj. 33903, n 480/ Invent. 1798, Clase 5a , fajo 9, ${ }^{\circ} 1$. 
-1507-11-09.- Burgos

Real Provisión de Juana I de Castilla y el Consejo de ese reino, nombrando al licenciado Vargas comisario para hacer averiguaciones sobre la entrada años atrás de los de Alfaro a mano armada en Niencebas, arrasando las casas y torres de los baños y el hospital de peregrinos, causando daños valorados en 2.000 florines. Al parecer, semejante despropósito se había realizado en represalia por el derribo de mojones en Alfaro hecho por criados del monasterio de Fitero.

AGN, Clero, Fitero, caj. 33854, n 208 . Original en papel con sello de placa/ Invent 1798, Clase $5^{\text {a }}$, fajo $9, n^{\circ} 5$.

-1507.- Logroño

Reconstrucción de mugas hecha por el corregidor de Logroño.

AGN, Clero, Fitero, caj. 33903, nº 471/Invent. 1798, Clase 5 $5^{\text {a }}$ fajo 9, nº 3.

-1511-02-11.- Fitero

Fray Martín de Egüés, abad de Fitero, da a censo a Francisco González, sastre, vecino de Fitero, una pieza de tierra de dos robos en Peña Fitero para plantar viñas.

AGN, Clero, Pergaminos Fitero, n⿳ 442 (2). Original elaborado por Juan de San Juan notario de Fitero/ Invent. Ros, caj. 2, fajo 1, f. 41.

-1512-02-18.- Alfaro

Requerimiento del monasterio de Fitero a la ciudad de Alfaro sobre la destrucción de la presa y quema de los baños de Valdebaños.

AGN, Clero, Fitero, caj. 33903, n 480/ Invent. 1798, Clase 5 $5^{\text {a }}$ fajo 9, nº 6.

-1512-06-06.- Fitero

Martín de Egüés, abad de Fitero, dispone de los diezmos percibidos por el monasterio para el pago de ciertas obras de fábrica.

AHN, Clero, carp. 1401, n 13. Original con suscripción abacial/ Invent. 1634, caj. 3, fajo 4, $\mathrm{n}^{\circ}$ 8/ Invent. 1708, caj. 1, fajo. 4, nº 9/ Invent. 1798, Clase $5^{\text {a }}$, fajo único, no 38.

-1514-10-19.- Fitero

Fray Martín de Egüés, abad de Fitero, y el monasterio dan a censo a Francisco González unas heredades.

AGN, Clero, Pergaminos Fitero, nº 442 (3). Documento notarial/ Invent. 1634, caj. 2, fajo 1.

-1514.- Zaragoza

Sentencia del oficial del arzobispo de Zaragoza a favor de Fitero y contra Alfaro por el derribo de los baños de Valdebaños y torre de Niencebas.

AGN, Clero, Fitero, caj. 33859, no 267/ Invent 1798, Clase $5^{\text {a }}$, fajo $9, n^{\circ} 9$.

\section{CONCLUSIONES}

Sintetizando la información que se extrae del inventario, resulta que el corpus documental está formado por 162 documentos, de los que 79 son originales, cuya distribución cronológica es la siguiente:

$\begin{array}{lcc}\text { Siglo } & \text { Total documentos } & \text { Total originales } \\ & & \\ \text { XII } & 26 & 14 \\ \text { XIII } & 61 & 45 \\ \text { XIV } & 17 & 3 \\ \text { XV } & 48 & 12 \\ \text { XVI } & 10 & 5\end{array}$


No hay unos parámetros claros en la secuencia temporal pues si hay un verdadero salto en la producción escrita entre los siglos XII y XIII, se observa una disminución acentuada en el siglo XIV, no justificada en el plano teórico ya que el recurso al documento escrito estaba perfectamente asentado conforme los principios del Derecho común ya habían ganado el terreno a la tradición oral. El siglo XV retoma los altos niveles escriturarios pero sin llegar a alcanzar el nivel del siglo XIII. Así pues, la documentación conservada para los siglos XII y XIII es representativa del ambiente documental de esas centurias, no así la de los siglos XIV y XV. La pérdida documental es más evidente en el siglo XIV que en el XV.

En cuanto a la tradición documental, es interesante señalar el alto número de originales, que casi llega a la mitad del corpus. En cierto modo, la fundación más tardía de los monasterios cistercienses conllevaba que las escrituras tenían una datación más reciente que los benedictinos de origen hispano o cluniacense, por lo que los casos paradigmáticos que se daban en estos archivos de fundación altomedieval (falsificaciones, pseudo-originales, paso de la escritura visigótica a la carolina) quedaban aquí atenuados.

Este cuadro demuestra también la importancia de las copias para reconstruir el archivo ya que sin ellas, el caudal quedaría reducido en más de la mitad. Conviene indicar que contar con copias era una necesidad sentida por el propio monasterio. Era una medida preventiva ante futuras e inevitables pérdidas documentales. Los documentos se manejaban mucho. Había que presentarlos a los sucesivos reyes y papas para su confirmación. La posibilidad de su extravío era grande, por lo que una copia autenticada era una alternativa a este peligro. Conviene traer a colación el documento fechado en 12 de abril de 1258 que presentó Fitero en el tribunal de la Cort en 1570. El cenobio guardaba en su archivo el privilegio rodado expedido por Alfonso X (AHN, Clero, carp. 1399, $\mathrm{n}^{\circ}$ 3) pero presentó una copia (AGN, Clero, $\mathrm{n}^{\circ} 244$ ) impura si bien el concejo de San Pedro de Yanguas aceptó que no tuviera todos los requisitos legales ya que sabía que las idas y venidas del documento original "por miedo que les podría contecer algún engaño o alguna pérdida". En el siglo XVI el recurso a las copias era tan habitual, que Fitero solicitaba a los tribunales (Cámara de Comptos, Cort, Consejo real de Navarra) aquellos documentos que había perdido o que sabía que por su contenido les sería de utilidad para defender sus intereses en el futuro. Hay que tener presente que una donación del siglo XII mantenía su valor probatorio ante un tribunal en el siglo XV, por lo que la pérdida de un privilegio era una catástrofe para los intereses materiales del cenobio. La documentación medieval, que para nosotros es un arsenal historiográfico, para la comunidad cisterciense tenía un valor primordialmente jurídico y en segundo plano cronístico-hagiográfico.

Esto nos lleva a ligar la producción documental, su custodia en el archivo con el ambiente histórico que le tocó vivir, inmerso en continuas refriegas. Tanto su situación fronteriza entre Navarra, Castilla y Aragón, como la inseguridad conllevaban violencias en las que el monasterio resultaba ser la parte más débil. De ahí la necesidad de obtener al menos la seguridad jurídica de sus bienes mediante privilegios y salvaguardas de los reyes castellanos y navarros, así como la protección espiritual pontificia. Conforme la autoridad de la monarquía se asentaba, la violencia física se iba encaminando hacia derroteros institucionales. Tenían que ser los tribunales los que resolvieran las diferencias sin permitir el recurso a la violencia particular. Esto se lograba mediante el surgimiento o reforzamiento institucional. Así es como desde el siglo XIII surgen organismos que cada vez van a intervenir más en la vida cotidiana. Como consecuencia, la producción documental se multiplica, así como los organismos intervinientes. Surge la sociedad pleiteante ya que los roces son cada vez más frecuentes entre el monasterio y otros núcleos urbanos o con otros organismos civiles y eclesiásticos. La victoria del Derecho común y la implantación 
de estas instituciones de derecho público iban de la mano. También la sutilidad en la documentación, cuya tipología se multiplica y obliga a unos requisitos mínimos. Las copias tienen que dar fe bien por organismos públicos (vidimus) bien por el auge de los escribanos y notarías.

Esto queda demostrado en el siguiente cuadro en el que se clasifican los 162 documentos en función de su organismo productor. Hay que advertir que la tradicional división entre documentos reales, eclesiásticos y particulares no permite afinar la complejidad institucional, por lo que se ha optado por añadir otra casilla que recoja los documentos emanados de otras instituciones públicas que no sean los reyes (gobernadores, villas, adelantados, tribunales). Por otro lado, se ha tenido en cuenta el organismo productor, de modo que una venta de un vecino al monasterio queda englobada en el grupo de documentos particulares, pero si es el abad el que otorga un censo, queda entre los eclesiásticos. Casos más dudosos en su encuadre como convenios entre el monasterio y núcleos urbanos permitirían ponerlos tanto entre los eclesiásticos como entre los de instituciones, pero su volumen no es numeroso y el resultado global no queda muy alterado.

\begin{tabular}{|l|l|c|c|c|c|c|}
\hline & & s. XII & s. XIII & s. XIV & s. XV & s. XVI \\
\hline Reales & Castilla & 10 & 11 & 5 & 3 & 1 \\
\hline & Navarra & 2 & 2 & 2 & 12 & \\
\hline Eclesiásticos & Pontificios & 7 & 13 & 2 & 4 & 2 \\
\hline & Otros & 2 & 15 & 5 & 14 & 5 \\
\hline Instituciones & & 1 & 2 & 2 & 12 & 2 \\
\hline Particulares & & 4 & 18 & 1 & 3 & \\
\hline
\end{tabular}

Finalmente, el lector habrá comprobado la importancia de afinar la historia institucional con la diplomatística y la archivística. Partíamos de la premisa de los efectos devastadores de las guerras bajomedievales sobre Fitero pero sorprendentemente este discurso que viene repitiéndose desde el siglo XVII por los archiveros monásticos y los historiadores actuales, a lo que se ha venido a sumar la francesada y la desamortización de Mendizábal, se han convertido en tópicos no siempre explicativos de una realidad más compleja. Que influyeron estos episodios de violencia es indudable, pero que esta sea la explicación unívoca de la destrucción del patrimonio documental de un cenobio no es cierto. Queda demostrado que la sociedad violenta bajomedieval y pleiteante en época moderna conllevaron una continua erosión documental. Los documentos iban y venían. Como bienes muebles, fáciles de transportar, eran fáciles de salvaguardar ante devastaciones bélicas (al igual que los manuscritos o el tesoro litúrgico) pero es bien cierto el adagio de que dos traslados de papeles equivalen a un incendio. Los documentos entraban y salían para buscar confirmaciones de las altas instituciones, para presentarlos en los pleitos o para ponerlos a salvo de pillajes. Desde el siglo XVI los priores echaban de menos ciertos privilegios cuya ausencia se preocuparon de rellenar mediante copias. En 1708 el inventario del archivo señalaba que la donación de Pedro Tizón no estaba en su lugar correspondiente. Estos antiguos instrumentos de descripción resultan de gran utilidad para seguir la pista de la documentación medieval. De hecho, buena parte de los documentos del siglo XIV son conocidos por sus asientos ya que no se han conservado los originales ni las copias.

Fecha de recepción del artículo: Marzo 2010

Fecha de aceptación y versión final: Mayo 2010 